\title{
Богдан Смерека
}

\section{СТАРОСІЛЬСЬКА МАЕТНІСТЬ У ЛЬВІВСЬКІЙ ЗЕМЛІ РУСЬКОГО ВОСВОДСТВА: ТЕРИТОРІЯ І НАСЕЛЕННЯ У ХVI-XVII СТ.}

Представники княжого роду Острозьких, свого часу чи не найвпливовіші на Волині, володіли низкою поселень поза межами регіону, в т. ч. у Руському воєводстві. Серед них, зокрема, маєтковий комплекс у Львівській землі $з$ центром у Старому Селі. Тут у 80-х роках XVI ст. Острозькими було зведено ренесансний замок (за проектом Амвросія Прихильного), який у 1642 р. перебудували в маньєристичному стилі. На вбудованій у східну вежу плиті було викарбувано пам'ятний напис про фундатора реконструкції кн. Владислава-Домініка Заславського: WDXOYZWSLS (Wtadystaw Dominik Xiązę Ostrogski y Zasławski Wojewoda Sandomierski Lucki Starosta).

У запропонованій статті спробуємо відповісти на ряд питань, зокрема, встановимо, хто володів Старосільським маєтковим комплексом упродовж всього часу його існування та в який спосіб його набули у власність Острозькі і Заславські, дослідимо перебіг територіального розширення комплексу, розглянемо історико-демографічні аспекти його розвитку.

Слід зауважити, що цілісно Старосільський ключ у науковій літературі не розглядався. Історією окремих населених пунктів в його складі займалися краєзнавці Антоній Шнайдер ${ }^{1}$ та Василь Лабаㄹ․ Поселенням присвячені також короткі гасла в краєзнавчих довідкових виданнях ${ }^{3}$. Чимала історіогра-

${ }^{1}$ Schneider A. Staresioło pod Lwowem // Dodatek Miesięczny do Gazety Lwowskiej: poswięcony historyi, statystyce i ekonomii krajowej. - Rok 1. - T. 2, zesz. 5. - Maj 1872. - Lwów, 1872. - S. 3-15; zesz. 6. - Czerwiec 1872. - S. 68-80. Шнайдер видав цей матеріал окремою брошурою під псевдонімом “А. Сарторіуш”: Staresioło pod Lwowem / opisał A. Sartoriusz. Lwow, 1872. - 30 s.: ill. На українську мову її переклав Василь Лаба: Шнайдер А. Старе Село під Львовом / Переклад з польської мови та передмова В. Лаби. - Львів, 1996. - 22 с.

2 Лаба В. Історія села Великі Глібовичі від найдавніших часів до 1939 року. - Львів, 2002. - 36 с.; Його ж. Історія села Городиславичі від найдавніших часів до 1939 року. - Львів, 1997. - 20 с.; Його ж. Історія села Гринів від найдавніших часів до 1939 року. - Львів, 1997. - 16 с.; Його ж. Історія села Під’ярків від найдавніших часів до 1939 року. - Львів, 1997. - 20 с.; Його ж. Історія села Підгородище від найдавніших часів до 1939 року. - Львів, 1997. - 20 с.; Його ж. Історія села Романів від найдавніших часів до 1939 року. - Львів, 1997. - 19 с.; Його ж. Історія села Шоломия. - Львів, 1997. - 72 с.; Його ж. Літопис парафії Звенигород від давніх часів до 1939 року. - Львів, 2011. - 52 с. : іл., фотоіл.; Його ж. Літопис парафії Підмонастир від давніх часів. - Львів, 2016. - 80 с. : іл., портр., фотоіл.; Його ж. Літопис церковного та культурного життя села Підсоснів від давніх часів до 1939 року. - Львів, 2016. - 44 с.

3 [Anonim]. Budków // Słownik geograficzny Królestwa Polskiego i innych krajów 
фічна спадщина стосується хіба що Звенигорода, однак дослідники, в основному, звертають увагу на його розвиток у княжий період 4 . Обставини переходу Старого Села та Звенигорода в шляхетську власність наприкінці XIV та на початку XV ст. розглянув польський історик Януш Шишка 5 . Також дослідник детально висвітлив історію власницької приналежності (до третьої чверті XVI ст.) коронних сіл Відники, Гаї, Пліхів, Підсоснів та Під’ярків, що у XVIII ст. увійшли до складу розглянутого нами ключа'

Територія. Старосільський маєтковий комплекс займає південно-східні терени сучасного Пустомитівського і північно-західну частину Перемишлянського районів Львівської області. У геоморфологічному відношенні ця територія відзначається горбистим рельєфом - практично вся (за винятком північної частини, що належить до Грядового Побужжя) вона зайнята ма-

słowiańskich (далі скорочення: SG). - Warszawa, 1880. - Т. 1 / Pod redakcją F. Sulimierskiego, B. Chlebowskiego i W. Walewskiego. - S. 440; R[ozwadowski] B. Chlebowice Wielkie // SG. T. 1. - S. 582; Ibid. Dźwinogród // SG. - Warszawa, 1881. - T. 2 / Pod redakcją F. Sulimierskiego, B. Chlebowskiego i W. Walewskiego. - S. 310-311; [Anonim]. Horodysławice // SG. - Warszawa, 1882. - T. 3 / Pod redakcją F. Sulimierskiego, B. Chlebowskiego i W. Walewskiego. - S. 142; [Anonim]. Hryniów // SG. - Warszawa, 1882. - T. 3. - S. 194; [Anonim]. Hucisko // SG. - Warszawa, 1882. T. 3. - S. 202; Mac[iszewski M.], R[ozwadowski] B., Dz[iedzicki] L. Huta Suchodolska // SG. Warszawa, 1882. - T. 3. - S. 235; Dz[iedzicki] L. Kocurów // SG. - Warszawa, 1883. - T. 4 / Pod redakcją F. Sulimierskiego, B. Chlebowskiego i W. Walewskiego. - S. 236; Ibid. Łopuszna (z Mielnikami) // SG. - Warszawa, 1884. - T. 5 / Pod redakcją F. Sulimierskiego, B. Chlebowskiego i W. Walewskiego. - S. 728; Ibid. Mikołajów // SG. - Warszawa, 1885. - T. 6 / Pod redakcją F. Sulimierskiego, B. Chlebowskiego i W. Walewskiego. - S. 402; [Maurycy] Mac[iszewski M.], $R$ [ozwadowski] B., Dz[iedzicki] L. Olchowiec// SG. - Warszawa, 1886. - T. 7 / Pod redakcją B. Chlebowskiego i W. Walewskiego. - S. 452; Dz[iedzicki] L. Podhorodyszcze // SG. - Warszawa, 1887. - T. 8 / Pod redakcją B. Chlebowskiego i W. Walewskiego. - S. 399-400; Ibid. Podjarków z Wańkowcami // SG. - Warszawa, 1887. - T. 8. - S. 400; Ibid. Podmanasterz // SG. - Warszawa, 1887. - T. 8. - S. 436; Ibid. Podsosnów // SG. - Warszawa, 1887. - T. 8. - S. 470; Ibid. Romanów // SG. - Warszawa, 1888. - T. 9 / Pod redakcją B. Chlebowskiego i W. Walewskiego. - S. 722; $R[$ ozwadowski] B., Dz[iedzicki] L. Siedliska // SG. - Warszawa, 1889. - T. 10 / Pod redakcją B. Chlebowskiego i W. Walewskiego. - S. 512; Dz[iedzicki] L. Stare Sioło // SG. - Warszawa, 1890. - T. 11 / Pod redakcją B. Chlebowskiego i W. Walewskiego. - S. 242-243; Ibid. Suchodoł // SG. - Warszawa, 1890. - T. 11. - S. 535-536; Ibid. Szołomyja // SG. - Warszawa, 1892. - T. 12 / Pod redakcją B. Chlebowskiego. - S. 17; Ibid. Wołoszczyzna // SG. - Warszawa, 1893. - T. 13 / Pod redakcją B. Chlebowskiego. - S. 897; [Анонім]. Великі Глібовичі // Історія міст і сіл Української PCР: В 26 т. Львівська область / Ред. кол. тому: Маланчук В.Ю. (гол. редкол.), Пастер П.І. (відп. секр. редкол.) та ін. - Київ, 1968. - С. 569-570; [Анонім]. Романів // Там само. - С. 572; [Анонім]. Суходіл // Там само. - С. 573; Грабовецький В.В., Мельник Б.О. Звенигород // Там само. - С. 584-592; [Анонім]. Миколаїв // Там само. - С. 602-603; [Анонім]. Старе Село // Там само. - С. 604-605.

${ }^{4}$ Серед праць, що частково торкаються історії Звенигорода в ранньомодерний період, див.: Влох M. Винники. Звенигород. Унів та довкільні села: історично-мемуарний збірник. - Чікаго, 1970. - 527 с.: іл.; Голубець М. Белз-Буськ-Звенигород. - Львів, 1927. - 32 с.; Грабовецький В. Звенигород. - Львів, 1959. - 65, [2] с.: іл.

${ }^{5}$ Szyszka J. Formowanie i organizacja dóbr monarszych w ziemi lwowskiej od połowy XIV do początku XVI wieku. - Kraków, 2016. - S. 68-69.

${ }^{6}$ Ibid. - S. 257-262. 
сивом Львівського Опілля. Зокрема тут (на південь від с. Романів) знаходиться найвища точка кряжу - гора Камула (471 м). Також через територію комплексу проходить Головний європейський вододіл. Тут беруть початок дві невеликі притоки Полтви (Ліва і Права Білка), що впадає у Західний Буг (басейн Вісли), ще кілька (Селисько, Давидівка, Бібрка) живлять Дністер (див. мапу 1). Власне, останні «розтинають» масив Львівського Опілля на кілька заліснених гряд - Давидівську, Бібрську та ін.

Впродовж всього часу існування Старостільського ключа його межі iз сусідніми маєтностями уточнювалися в результаті проведення щонайменше чотирьох ${ }^{7}$ розмежувань:

1. Не пізніше березня 1509 р. між селами Лопушна і Селисько (власність Миколая Дідушицького). Сам акт розмежування не виявлено, про його здійснення дізнаємося $з$ декрету короля Сигізмунда I у справі Дерслава Вільчка проти Барбари Тарновської, датованого 10-м квітня 1509 р.

2. 9 грудня 1595 р., проведене у Старому Селі комірником Яном Запольським між селом Глібовичами та маєтками Анни, вдови сондецького каштеляна Станіслава Стадніцького, та Зоф’ї, вдови Яна Олесьніцького (село Ходорківці і містечко Сенява, або Соколівка);

${ }^{7}$ Відомо, що на межі Старосільської маєтності, яка проходила між селами Давидів і Шоломия, також були насипані копці, однак коли саме - невідомо (знаємо лише про розмежування Давидова із селами Виннички, Гончарі та Дмитровичі, проведене у 1544 р.). На наявність копців вказує інцидент, зафіксований у львівських гродських актах: у 1603 р. шоломийські селяни зрили їх, самовільно захопивши давидівські орні землі, див.: Львівська національна наукова бібліотека України ім. В. Стефаника. - Відділ рукописів (далі скорочення: ЛННБ України. - ВР). - Ф. 141 [Архів Александра Чоловського], оп. 1, спр. 1603, с. 1-5; Центральний державний історичний архів України у Львові (далі скорочення: ЦДІАЛ). - Ф. 9 [Львівський гродський суд], оп. 1, спр. 390, с. 850-852; Horn M. Walka chłopów czerwonoruskich z wyzyskiem feudalnych w latach 1600-1648. - Cz. 3. - Warszawa-Wrocław, 1982. - S. 36.

${ }^{8}$ Після проведення розмежування сіл Лопушна і Селисько, у земському суді розглядалася справа львівського підкоморія Дерслава Вільчка проти Барбари Тарновської - остання звинувачувалася у порушенні меж (movisset termini). Вирок суду на користь Дерслава спонукав Барбару подати апеляцію до королівського суду. У декреті, вміщеному до Коронної метрики, монарх також визнав Барбару винною через іiї неявку на суд (Archiwum Główne Akt Dawnych w Warszawie (далі скорочення: AGAD). - Metryka Koronna (далі скорочення: MK), sygn. 23, k. 264-264 v. [s. 521-522]; регест: Matricularum Regni Poloniae summaria, excussis codocibus, qui in Chartophylacio Maximo Varsoviensi asservantur, contexuit indicesque adiecit Theodorus Wierzbowski (далі скорочення: MRPS). - Pars 4, vol. 1. - Varsoviae, 1910. - P. 35, nr 551.

${ }^{9}$ ЦДІАЛ. - Ф. 10 [Львівський земський суд], оп. 1, спр. 39, с. 231-236; регест: Akta grodzkie i ziemskie z czasów Rzeczypospolitej Polskiej z archiwum tak zwanego bernardyńskiego we Lwowie w skutek fundacyi śp. Alexandra hr. Stadnickiego (далі скорочення: AGZ). - T. 10 / [Oprac. O. Pietruski, X. Liske]. - Lwów, 1884. - S. 175, nr 2715. Згадані такі об’єкти: ad vallem al[ia]s Do Debrzÿ; vallem al[ia]s Pod Tuczną; in arbore Hornÿ; in arbore Bilie; sub arbore Storni (c. 233); alterius vallis al[ia]s Debrzyczkie (c. 233-234); supra vallem al[ia]s Nad Debrzą pod grabem pochelnem; supra vallem Wołczowa; circa campu[m] argulea Wasilkowi; supra vallem Dinistrowego Kąta; ad montem Manasterski; versus vallem al[ia]s ku Debrzÿ (c. 234); supra vallem Hrynczowego Garbu; p[er] alia cam[p]o Wołczkoweÿ Kopanÿ; via[m] Wołczkowa de Hlibowicze et Hodorkowcze tenden[s] (c. 235). 

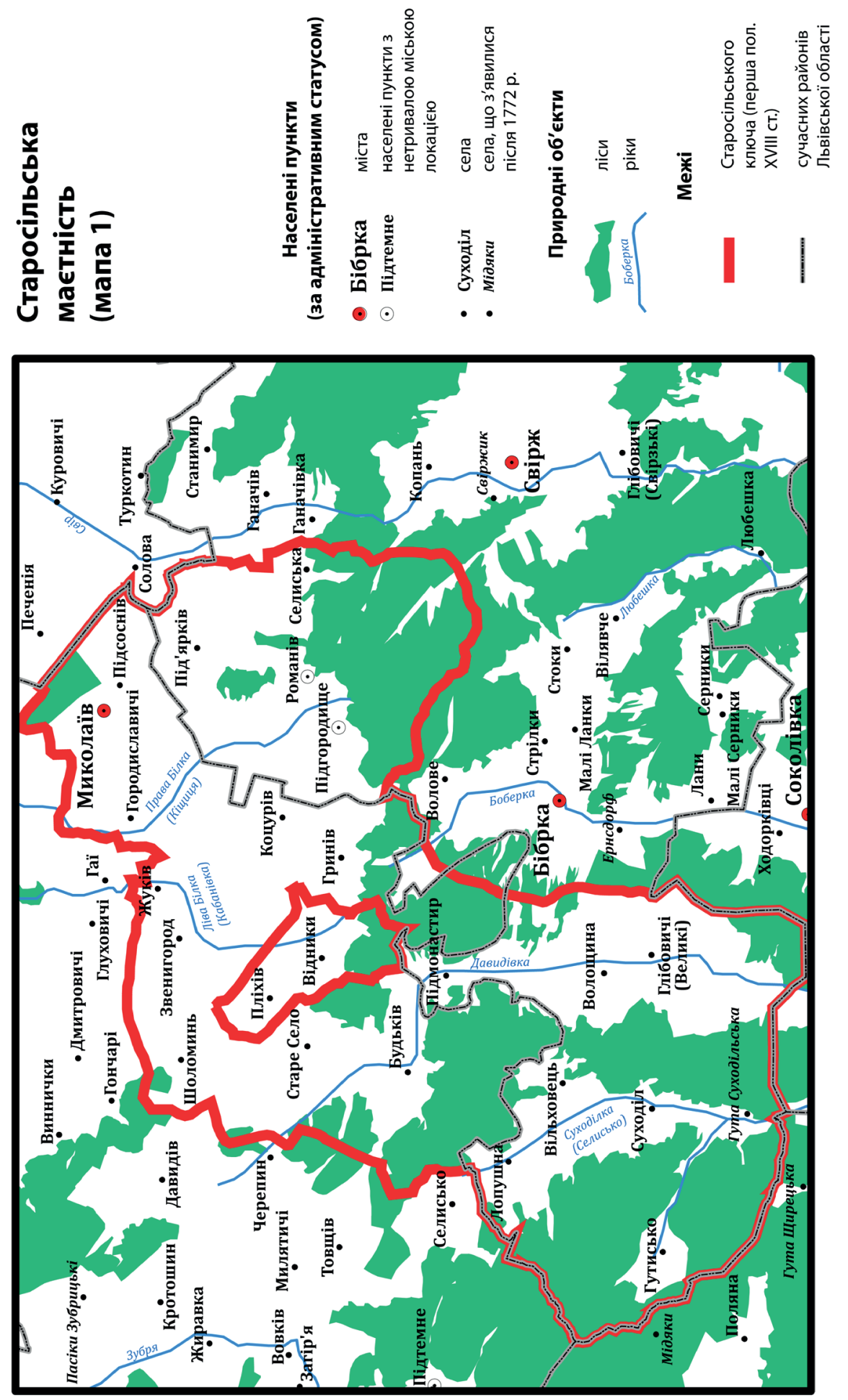
3. 16 травня 1601 р. за участі того ж комірника Запольського між селами Свірж (власність Кшиштофа Свірзького), Романів і Підгородище (володіння руського воєводи Гієроніма Сенявського, згодом увійшли до Старосільського ключа), а також Ганачевом (власник Клеменс Клюс) та Селиськом (Анджей та покійний на момент розмежування Кіліан Лагодовські $)^{10}$.

4. 31 липня 1603 р., здійснене в лісі Словіча між Красовом і Поршною Яном Запольським (на той момент - підкоморієм Львівської землі) між селами - з одного боку Красів і Поршна (Щирецьке староство, на той момент в тенуті львівського старости Сжи Мнішка), з другого боку Млинівці, Підтемне і Монастир (власність львівського мечника Миколая Нарайовського), з третього боку Старе Село і Лопушна ${ }^{11}$.

Власники. Наприкінці XIV ст. власниками Старого Села та навколишніх поселень були представники родини Горайських герба Корчак - Михайло Жаба 3 Княгинич та його двоюрідний брат ${ }^{12}$ коронний маршалок Дмитро з Горая ${ }^{13} .5$ квітня 1399 р. останній продав 18 власних сіл познанському єпископу Миколаєві з Курова, його батькові Клеменсу та братам Яну, Клеменсу і Пйотру за 3000 гривень ${ }^{14}$.

${ }^{10}$ ЦДІАЛ. -Ф. 10, оп. 1, спр. 40, с. 1435-1446; регест: AGZ. - Т. 10. - S. 186, nr 2913. Згадані такі об'єкти: ad sylua[m] Temne (c. 1436); in sumitate al[ia]s na wierzchowinie luto dicto Mschany (c. 1439); per vallem al[ia]s przez doline; uallem al[ia]s Wyboiem usq[ue] ad merica[m] dicta[m] Dolhe; alterius montis Wielkie Kąta; ab villam Stoki na moczisko dicto Stricholowi; silua dicta Borsowa (c. 1440).

${ }^{11}$ Там само. -Ф. 10, оп. 1, спр. 99, с. 1299-1313, 1314-1315; регест: AGZ 10. - S. 189, nr 2970. Згадані такі об’єкти: sylua dicta Słowicza (c. 1299); terrae aliis mogiły Dupna (c. 1299), locu[m] dictu[m] Zielona Krynica (c. 1307); las Kuzczyn (c. 1308); in montem Działem Stryniowskim; inter uroczysza Piekarnia; inter syluas ex parte dextra Suchey Bobrowki; via Moczara Chymna (c. 1309); valle dicta Janowa sub monte et sylua Derewacz (c. 1312); monte dicto Szymkowa gora; ad vallem dict[um] Kamienna Debcza; ad vallem al[ia]s do Debczy Kryniczney; ad vallem dict[um] Łazew (c. 1313); pratum dict[um] Zam[...]yszowsky (c. 1314).

12 За однією з версій, Дмитро з Горая і Михайло Жаба-рідні брати, їхній батько - жидачівський воєвода Петро Жаба (Red[aktor główny Konopczyński W.]. Dymitr z Goraja // Polski Słownik Biograficzny (далі скорочення: PSB). - Kraków, 1948. - T. 6. - S. 61-62). На думку Володимира Пшика, Дмитро з Горая був сином одного з братів Петра Жаби - Ходка або Осташка (Пиик B. Петро - перший жидачівський воєвода та його найближча родина // Галицька брама. - Львів, 1999. - №o 3-4: березень-квітень (№№ 51-52). - С. 6-7).

1316 жовтня 1378 р. руський староста Андраш (Андрій) засвідчив акт передачі Михайлом Жабою з Княгинич своєї власності Дмитру (у документі іменується «Demetrius de Lada») у випадку своєї безпотомної смерті (Zbiór dokumentów małopolskich (далі скорочення: ZDM). Cz. 4 / Wyd. S. Kuraś, I. Sułkowska-Kuraś. - Wroclaw, 1969. - S. 227-228, nr 1075; оригінал: Biblioteka Czartoryskich w Krakowie, pergamin nr 205).

14 Володіння Дмитра знаходилися в Буській землі, а також у Львівському, Галицькому i Снятинському повітах Руської землі: Бережани, Будьків, Вовчківці, Глібовичі, Гончарі, Гринів, Дев’ятники, Дубовичі (Дубівці), Княгиничі, Лопушна, Підмонастир, Рибничі, Старе Село, Суходіл, Товщів, Черепин, Чишки, Шоломия. 3 них до Старосільської маєтності належало щонайменше 11 (Katalog dokumentów pergaminowych ze zbiorów Tomasza Niewodniczańskiego w Bitburgu / Oprac. J. Tomaszewicz i M. Zdanek; red. W. Bukowski (далі скорочення: Katalog Niewodniczańskiego). - Kraków, 2004. - S. 16-17, nr 35). 
Близько 1425-1426 pp. ${ }^{15}$ Пйотр 3 Курова передав Старосільську маєтність у володіння Завіші Чорному з Гарбова. 3 чотирьох синів останнього (Станіслав, Марцін, Завіша та Ян) співвласниками ключа було троє молодших (Станіслав загинув у 1444 р. під Варною). Впродовж 1450-1452 рр. померли бездітними Марцін (у 1443 р. придбав солтиство у Старому Селі за 800 гривень) і Завіша, а в 1454 р. в бою під Хойницями і Ян, кольський староста. Надалі маєтність утримували його діти - син Ян Завіша (помер нежонатим перед 1499 р.) і донька Барбара ${ }^{16}$.

У власності родини в цей період, окрім названих поселень, перебували також Глібовичі: у 1447 р. Марцін повідомив возному про погашення податкового боргу (з подимного) в т. ч. 3 цього села ${ }^{17}$. Припускаємо, що до володінь Завіш в цей час належали також Суходіл ${ }^{18}$, Вільховець $^{19}$, Будьків ${ }^{20}$ та Монастир ${ }^{21}$ (тепер Підмонастир).

${ }^{15}$ Наше припущення грунтується на тому, що саме в ці роки Куровський продав інші свої села - Рожнув і Грудек (тепер Грудек-над-Дунайцем) біля Нового Сонча - Завіші Чорному (Boniecki A. Herbarz Polski. - Warszawa, 1902. - T. 13. - S. 245). А. Шнайдер помилково зазначає, що Завіша Чорний набув у власність Старе Село ще у 1401 p. (Schneider A. Staresioło pod Lwowem. - S. 6).

${ }^{16}$ Boniecki A. Herbarz Polski. - Warszawa, 1902. - T. 5. - S. 367.

${ }_{17}$ AGZ. - T. 14 / [Oprac. O. Pietruski, X. Liske]. - Lwów, 1889. - S. 236, nr 1876 (23.III.1447; Gsus. Nicolaus procurator dom. Martini Zawisschycz de Staresyolo citatus per Nicolaum Ministerialem castri jak wyżej repercussit pignus duplex pro fumalibus de villis Staressyole et de Hlebowicze).

${ }^{18}$ Ibid. - T. 15 / [Oprac. O. Pietruski, X. Liske]. - Lwów, 1891. - S. 354, nr 2668 (прибл. 4.V.1498. Pop Rutenum de Suchodole hominem dom. Cstli. Cracov.); s. 355, nr 2682 (22.VI.1498; Suchodol tenuta mfi. dom. Castlli. Cracov).

${ }^{19}$ Першу згадку про село вдалося зафіксувати в першому поборовому реєстрі Львівської землі 1510 р. (див. табл. 1) серед власності родини Тарновських.

${ }^{20}$ Ibid. - S. 106, nr 759 (27.VII.1470; gsam. Barbaram de Staresyolo et de Buthkow consortem gsi. Stanislai de Thaczhyn Succam. Chelmen.).

${ }^{21} \mathrm{~B}$ «Aktach grodzkich i ziemskich» знаходимо запис про втечу кількох мешканців с. Монастир (володіння Завіші) до села Суходіл, чому Михайло Прокопович (очевидно, власник Суходолу) не завадив, див.: Ibid. - T. 14. - S. 337, nr 2597 (30.VI.1452). Михайло Прокопович був сином Прокопа Тептюковича, рідного брата Васька (Вахна) Тептюковича з Тисмениці. У їхньому володінні перебували села Підбір'я та Стрілища - останні у 1417 p. отримали магдебурзьке право (Materiały archiwalne, wyjęte głównie z Metryki Litewskiej od 1348 do 1605 roku / Wyd. A. Prochaska. - Lwów, 1890. - S. 25, 26, nr 35). Власне, ім’я Михайла Прокоповича часто згадується в джерелах 3 приставкою «зі Стрілищ» та «з Підбір'я», див.: AGZ. - T. 14. - S. 360, nr 2762 (21.II.1453; nobil. Michael de Strelcze Procopowicz); s. 473, nr 3532 (12.III.1456; nobil. Michaelem Procopowycz de Podborz pro tribus bobus et septemdecim marcis, prout inscripsit se sibi sub intromissione Suchodolcze [...] sed Suchodol); s. 474, nr 3538 (2.IV.1456); s. 478, nr 3563 (17.V.1456); s. 481, nr 3576 (28.V.1456); t. 15. - S. 20, nr 130 (22.VII.1457). На нашу думку, згадане в контексті втечі селян село Суходіл не має відношення до Старосільської маєтності. Йдеться про зникле поселення з аналогічною назвою (також відоме як Суходольче та Суходолець), розташоване неподалік с. Підбір'я. На це вказує фрагмент тексту підтвердження Владиславом Ягайлом надання Владислава Опольського сіл Стрілища, Вербіж і Микитинці Ваську Тептюковичу на ленному праві від 26 жовтня 1416 р.: villarum, nostras infrascriptas, quas ipse Waszko ad presens obtinet, videlicet: Podborze circa fluvium Lubscha cum quadam planicie circa Szwyrzsz fluvium, dicta Suchodol, pro locacione ville 
Натомість, ще в першій половині XV ст. від родини відійшли Гринів та (тимчасово) Лопушна 22 : у 1439 р. Марцін записав 200 гривень на цих селах Мірошку (Мирославу) Камйонацькому ${ }^{23}$, вихідцю з Камйоначика під Серадзем. В середині XV ст. власником Гринева також виступав родич Мірошка на ім'я Добеслав (Добек) ${ }^{24}$.

Надалі це село разом із сусіднім Коцуровом ${ }^{25}$ належало дітям місцевого шляхтича Станіслава Митулинського - Влодкові ${ }^{26}$ та Катерині ${ }^{27}$ (Влодко в джерелах названий також власником сіл Передин і Краслинчичі - у випадку останнього можемо стверджувати, що йдеться про зникле поселення, розташоване неподалік Коцурова ${ }^{28}$ ). Катерина Митулинська (Коцурівська) була дружиною Протаса ${ }^{29}$ - обоє в документах іменуються державцями

[курсив наш - Б.С.], див.: AGZ. - Т. 5 / [Oprac. O. Pietruski, X. Liske]. - Lwów, 1875. - S. 39, nr XXX.

${ }^{22}$ Починаючи 3 першого поборового реєстру Львівської землі 1510 р. село згадується в переліку володінь Тарновських, відтак можемо його вважати спадщиною родини Завіш (AGAD. - Archiwum Skarbu Koronnego (далі скорочення: ASK), dział 1 [Rachunki Królewskie 1388-1781], sygn. 20, k. 170 v.).

${ }^{23}$ Після смерті Мірошка та виплати коштів Завішами села повинні були повернутися до останніх, див.: AGZ. - Т. 14. - S. 97, nr 762 (7.VI.1443; Mirosch de Camyonacz); s. 175, nr CDXCV (26.VI.1445; Mirosch de Granyow); s. 179, nr 1432 (23.VII.1445); s. 180, nr DVI (30.VII.1445; Miroslao de Granyow); Katalog Niewodniczańskiego. - S. 28, nr 60.

${ }^{24}$ Ibid. - S. 237, nr 1890 (24.IV.1447; Dobkonem de Camyonacz).

${ }^{25}$ На початку XV ст. село, ймовірно, належало Якубу Коцурівському (9.III.1410; AGAD. MK, sygn. 46, k. 27 v.-28; perест: MRPS. - Varsoviae, 1915. - Pars 4, vol. 3. - P. 373, supplement nr 479).

${ }^{26}$ AGZ. - T. 14. - S. 276, nr 2150 (6.XII.1448; nobil. Wlodkonem Mithulynski tenutarium in Hranyow); s. 363, nr 2774 (16.III.1453; nobili Wlot[kom] de Hranyow tenebatur); s. 383, nr 2914 (10.VIII.1453; Nobil. Włodek de Hranyow alias de Coczurow); s. 386, nr 2934 (15.IX.1453), nr 2935 (29.IX.1453; Włodek nobilis de Przedrzyno alias de Coczvrow attemptavit terminum ab homine ipsius Anco Layecz pastuch de Hranyow); s. 387, nr 2943 (13.X.1453); s. 390, nr 2960 (6.XI.1453); s. 393, nr 2978, 2979 (7.XII.1453); s. 395, nr 2992, 2993 (21.XII.1453), nr 2994 (22.XII.1453); s. 411-412, nr 3121 (24.V.1454; nobil. Wlodek de Coczarow / nobil. Wlotkonis Coczarowsky); s. 417, nr 3152 (19.VIII.1454), nr 3153 (19.VIII.1454); s. 419, nr 3168 (2.IX.1454), nr 3172 (5.IX.1454); s. 421-422, nr 3189 (15.IX.1454); s. 471, nr 3516 (20.II.1456); s. 472, nr 3523 (5.III.1456); s. 473, nr 3534 (19.III.1456); s. 511, nr 3823 (31.V.1454); t. 15. - S. 26, nr 175 (11.XI.1457); s. 421, nr 3127 (20.II.1461); t. 19 / [Oprac. A. Prochaska]. - Lwów, 1906. - S. 502, nr 2801 (25.IX.1461; Nblis. Wlodek de Przedzyn alias de Cocyerow filius nblis. Stanislai de Mithulyn); s. 503 , nr 2802, 2803 (25.IX.1461).

${ }^{27}$ Ibid. - T. 14. - S. 275, nr 2139 (22.XI.1448; gsam. Katherinam Mithulynska tenutariam bonorum Hranyow); t. 15. - S. 196, nr 1558 (20.XII.1476); s. 491, nr 3859 (19.IV.1478), nr 3860; s. 492, nr 3872 (26.VI.1478); t. 19. - S. 176, nr 877 (11.XI.1476); s. 178, nr 890 (13.I.1477); s. 179, nr 896 (24.II.1479; nblem Katherinam consortem nobilis Coczurowsky); s. 194, nr 1005 (9.VI.1482); s. 213 , nr 1138 (19.V.1488); s. 243, nr 1356 (23.I.1486); s. 248, nr 1375 (3.IV.1486); s. 253-254, nr 1403 (11.IV.1485); s. 257, nr 1424 (18.VI.1487); s. 260, nr 1433 (7.I.1488), nr 1438 (19.V.1488); s. 485, nr 2691 (перед 1446; gsam. Katherinam uxorem Stanislai Mythulynsky).

${ }^{28}$ Ibid. - T. 14. - S. 505, nr 3759 (19.V.1452; Inter dom. Nicolaum Romanowski et Wlodkonem tenutarium in Hranyow terminus est positus ad limitandum una septimana post pros. f. Assumpcionis Marie inter Koczerow et Kraclynczicze et infra hinc non debent falcare).

${ }^{29}$ Достатньо рідкісне ім'я чоловіка Катерини Коцурівської спонукає до припущення, що йдеться про Протаса з Бортник та Скоморох. В середині XV ст. він займав уряд жидачівського 
(tenutarios) названих сіл ${ }^{30}$ (вочевидь, брат Влодко помер значно раніше за Катерину).

Ще однією власницею Коцурова була Мілохна (Клара ${ }^{31}$ ), одружена 3 Мацеєм (Матіасом ?) Голдачем з Ульвівка (або Ульгувека) ${ }^{32}$ (пізніше відомий в документах як Голдач з Заланева (de Zalunyewye) $)^{33}$. Мілохна-Клара була

підкоморія (ні попередників, ні наступників у Протаса не було - надалі цей уряд «автоматично» обіймав кожен львівський підкоморій). Якщо наше припущення вірне, то Катерина була його другою дружиною. 3 першою - Федькою, донькою Сенька Лопатича з Осталович, - він розлучився ще у 1450 р. 3 записів у гродських актах, що стосуються процесу розлучення, дізнаємося, що обоє були православними українцями (Urzędnicy województwa ruskiego XIVXVIII wieku (ziemie halicka, lwowska, przemyska, sanocka): spisy / Oprac. K. Przyboś. - Wrocław, 1987. - S. 177, nr 1446; AGZ. - T. 14. - S. 163, nr 1323 (8.III.1445); s. 168-169, nr 1358; s. 169, nr 1360, 1361 (10.IV.1445); s. 187, nr DXXV (17.IX.1445; Prothasio de Skomrochy Subcam. Zudaczou.); s. 244, nr 1939 (16.VIII.1447); s. 246, nr DCCXXXIV (5.X.1447); s. 270, nr 2107 (22.VII.1448); s. 272, nr 2120 (30.IX.1448); s. 275, nr 2134 (22.X.1448), nr 2135 (31.X.1448); s. 292, nr 2257 (17.VI.1450; nobil. Prothassium [de] Borthniki actorem et F[yedkam] uxorem eius ac Syenk[onem de] Lopathycz patrem Fyedcze), nr 2258-2261 (18.VI.1450; nr 2258); s. 293, nr 2265, 2267-2270 (18.VI.1450; nr 2269: nobil. Prothassium de Borthnyki ex una et Fyedkam Ruthenam uxorem legittimam. ipsius Prothassii Rutheni, filiam nobil. Syenkonis Lopathycz de Ostalowicz[e] pro et super certis [ar]ticulis super divorciacione matrimon[ii]); s. 298, nr 2299-2301 (10.VIII.1450); s. 299, nr 2308, 2310 (28.VIII.1450), nr DCCCXCIII (1 IX 1450)).

${ }^{30}$ AGZ. - T. 15. - S. 105, nr 743a (26.III.1470; nobil. Katherinam et Prothassium virum suos tenutarios in Coczarow); ЦДІАЛ. - Ф. 9, оп. 1, спр. 4, с. 146 (25.IV.1470; регест: AGZ. T. 10. - S. 9, nr 140).

${ }^{31}$ Під цим іменем Мілохна згадується у документі, датованому 5 січня 1498 р. (у львівські гродські акти помилково вписаний під 1598 р.), в якому йдеться про надання нею 350 гривень позики братам Пйотру, Отто і Рафалу з Ходча з правом зайняти їх дідичні села Матіїв та Руда (пізніше увійшли до складу Рогатинської королівщини) в разі несплати боргу (ЦДІАЛ. - Ф. 9, оп. 1, спр. 14. с. 289-290; регест: AGZ. - T. 10. - S. 12, nr 175).

32 Дослідники по-різному трактують згадки про представників родини Голдачів 3 приставкою «de Holkow / de Golkow / de Volkouysko» (AGZ. - T. 12 / [Oprac. O. Pietruski, X. Liske]. - Lwów, 1887. - S. 296, nr 3186 (4.VI.1464; nobili Mathie alias Goldacz de Golkow). На думку Адама Бонецького, йдеться про Вовків (не уточнюється, щоправда, про який саме) (Boniecki A. Herbarz Polski. - Warszawa, 1903. - T. 6. - S. 183). Анджей Янечек натомість пише, що син Мацея, Пйотр Голдач, локатор містечка Угринів, походив «з Залунева і Волковиськ у Галицькій землі» (Janeczek A. Osadnictwo pogranicza polsko-ruskiego: województwo bełskie od schyłku XIV do początku XVII w. - Wrocław, 1991. - S. 254; AGAD. - MK, sygn. 30, k. 46-47 (регест: MRPS. - Pars 4, vol. 1. - P. 147, nr 2532 (14.IX.1515; Petri Goldacz de Zalimow); k. 130 v.-131 (регест: MRPS. - Pars 4, vol. 1. - P. 154, nr 2648 (20.I.1518; Petro Goldacz de Wolkouiska)). Ряд документів XV-XVI ст. (надання Земовітом сіл в Белзькому повіті Павлові з Радзанова 1388 р., запис Казимира IV Анджею Магері з Переводова 1466 р. та ін.) дають можливість ототожнити Holkow / Golkow з Ульвівком біля Сокаля або ж із Ульгувеком неподалік Томашува (ZDM. - Cz. 4. - S. 235, nr 1083 (31.XII.1388, 17.II.1525; AGAD. - MK, sygn. 39, s. 231-234; регести: MRPS. - Varsoviae, 1912. - Pars 4, vol. 2. - P. 311, nr 14164; vol. 3. - S. 363, supplement nr $338 \rightarrow$ Wolchowo); MK, sygn. 35, k. 451-454 (11.XII.1466, 10.XI.1521; регести: MRPS. Pars 4, vol. 2. - P. 251-252, nr 13021; vol. 3. - S. 408, supplement nr $1001 \rightarrow$ Holkow); MK, sygn. 61, k. 256-257 (5.IV.1540; perect: MRPS. - Pars 4, vol. 3. - P. 150, nr $20258 \rightarrow$ Woltow); MK, sygn. 62, k. 302-304 (22.VIII.1541; регест: MRPS. - Pars 4, vol. 3. - P. 167, nr $20600 \rightarrow$ Holkow prope Sokal capitaneatus Belzensis)). Що стосується назви Volkouysko, то, ймовірно, йдеться про село Вилків біля Грубешева (пол. Wilków, Wołkowyja) (SG. - T. 13. - S. 875).

${ }^{33}$ AGZ. - T. 19. - S. 179, nr 897 (24.II.1479; Nblis. Mathias Goldacz [...] nbli. Katherina Coczurowska teszcza sua); s. 233, nr 1307 (18.I.1479). 
донькою Катерини, однак достеменно невідомо якої - чи згаданої вище, чи Катерини Авданцівни ${ }^{34}$, дружини ${ }^{35}$ Миколая Коцурівського ${ }^{36}$. В актових джерелах згадується інцидент, який трапився влітку 1474 р.: власник сусідньої маєтності Анджей Романовський пограбував Мілохну (з жінки було знято золоті та срібні коштовності, а також перли загальною вартістю 1000 гривень), викрав іï та «arestaret in fortalicio ${ }^{37}$ in Romanow» ${ }^{38}$. Деталі цієї витівки озвучував перед Львівським гродським судом Голдач. Замість Анджея у суді перебував його брат Якуб ${ }^{39}$ (детальніше про цю родину - нижче).

Половину Коцурова у 1461 р. утримував у заставі Пйотр з П’ящич (як і Камйонацькі, походив з Серадзького воєводства) ${ }^{40}$. Можливо, (спів)власниками села якийсь час були також Петро (Петрик $)^{41}$ та Іван ${ }^{42}$ Коцурівські, однак 3 огляду на брак джерел немає можливості стверджувати факт володіння. Не знаємо й про те, ким доводилися Іван і Петрик згаданим вище Коцурівським.

В XVI ст. Коцурів належав Цебровським (Чебровським). Зокрема в 1540 р., коли селом володів Вінцент Чебровський, воно отримало німецьке право ${ }^{43}$. До кінця століття власниками поселення у джерелах виступають Миколай ${ }^{44}$ (син Вінцента ${ }^{45}$ ), Ян ${ }^{46}$ і Маргарита ${ }^{47}$ Чебровські.

${ }^{34}$ Катерина Авданцівна походила 3 роду Авданців-Бучацьких - iї батьком був Мацько (Мачек) Авданець з Німшина та Рукомиша (AGZ. - T. 12. - S. 227, nr 2611 (9.IV.1453; nobili Mathie alias Awdanie[cz] de Rucomyeszye); s. 345, nr 3551 (7.I.1472; Nobil. Katherina filia olim nobil Mathie Awdanyecz de Nyenczyn).

${ }^{35}$ Ibid. - S. 374, nr 3811 (19.III.1470; nobil. Katherinam consortem nobil. Coczurowski); s. 409, nr 4101 (12.VII.1473; Nobil. Nicolaus Coczurowski cum sua consorte nobili Katherina).

${ }^{36}$ Ibid. - S. 359, nr CCLII (20.VI.1474; Nicolao de Coczurow); t. 14. - S. 166, nr 1344 (1.IV.1445); s. 507, nr 3180 (16.XI.1453); t. 15. - S. 165, nr 1285 (22.X.1473; nobil. Nicolaus Coczarowsky); s. 491, nr 3858 (1.V.1478); s. 492, nr 3871, 3874 (26.VI.1478).

${ }^{37}$ Мовиться або про темницю, або про замок, або про оборонний двір, див.: Пшик $B$. Укріплені міста, замки, оборонні двори та інкастельвані сакральні споруди Львівщини XIIIXVIII ст. (каталог-інформатор). - Львів, 2008. - С. 127.

${ }^{38}$ AGZ. - T. 19. - S. 525, nr 2912 (20.IX.1474).

${ }^{39}$ Ibid. - T. 17 / [Oprac. A. Prochaska]. - Lwów, 1901. - S. 438, nr 3637, 3638 (після 22.VIII.1474); t. 19. - S. 525, nr 2912 (20.IX.1474).

${ }^{40}$ Ibid. - T. 19. - S. 502, nr 2801 (25.IX.1461; Nblis. Wlodek de Przedzyn alias de Cocyerow filius nblis. Stanislai de Mithulyn recognovit, quia nbli. Petro de Pyaschczicze vendidit et resignavit mediam villam Coczerow in distr. Leop. pro septuaginta quinque marcis et obligatus est); s. 503, nr 2802 (25.IX.1461; Nblis. Petrus de Pyaschczicze recognovit, se teneri nbli. Wlodkoni de Cocyerow viginti et quinque marcas pro medietate ville Coczerzow).

${ }^{41}$ Ibid. - T. 14. - S. 413, nr 3129 (7.VI.1454; Nobil. Petrus de Coczvrow); t. 15. - S. 423, nr 3143 (1462); s. 431, nr 3238 (15.VI.1464; nobil. Pyetrzyk de Coczarow); s. 435, nr 3279 (14.VII.1464); s. 436-437, nr 3294 (8.VI.1464; Nobil. Petrus alias Pyetrzyk de Coczarow).

${ }^{42}$ Ibid. - T. 14. - S. 443, nr 3332 (7.V.1455; Iohanne Coczerowski).

${ }^{43}$ AGAD. - MK, sygn. 59, k. 324-325 v. (2.I.1540; perecr: MRPS. - Pars 4, vol. 3. - P. 140, nr 20066).

${ }^{44}$ AGAD. - ASK, dział 1, sygn. 19, k. 399 (1567).

${ }^{45}$ Ibid. - MK, sygn. 61, k. 306 v.-307 (20.IV.1540; регест: MRPS. - Pars 4, vol. 3. - P. 152, nr 20298); sygn. 67. - K. 308-308 v. (25.III.1545; регест: MRPS. - Pars 4, vol. 3. - P. 241, nr 21949).

46 Źródła dziejowe (далі скорочення: ŹD). - Warszawa, 1902. - T. 18, cz. 1 / [Wyd. A. Jabłonowski]. - S. 63 (1578 p.); AGAD. - ASK, dział 1, sygn. 19, k. 807 (1581 p.).

${ }^{47}$ AGAD. - ASK, dział 1, sygn. 19, k. 910 (1589 p.). 
Приналежність села Звенигород також вдається встановити 3 кінця XIV ст. На думку Я. Шишки, однією його частиною в цей період міг володіти згаданий вище Михайло Жаба, по смерті якого вона перейшла до Волчковичів (Ходорівських ${ }^{48}$. Останні у 1415 р. отримали другу половину Звенигорода - в цьому році Свенх (Свах) з Гранова (родич третьої дружини Ягайла Ельжбети Грановської) передав Дмитрові Волчковичу свою частину цього села, отримавши взамін Ходорківці і Сеняву у Львівській землі49. Надалі Звенигородом спільно володіли син Дмитра Станіслав Ходорівський ${ }^{50}$ та його дружина Ельжбета Бучацька ${ }^{51}$, хоча в джерелах поруч 3 іменами братів Станіслава - Яна та Юрші ${ }^{52}$ - також зустрічаємо формулювання «3 Ходорівставу та зі Звенигорода» ${ }^{53}$.

3 кінця XV ст. село утримував львівський підстолій Миколай Карнковський ${ }^{54}$ з Медухи ${ }^{55}$. У другому шлюбі з Фенною-Доротою (донькою Яна Коритка з Погірців) в Миколая було двоє синів. Старший син Ян обрав духовну кар'єру ${ }^{56}$, тому в 1515 р. продав Звенигород із сусіднім Жуковом братам Яну і Рафалу Кориткам ${ }^{57} .3$ чотирьох синів останнього власником Звенигорода джерела називають Бартоломея ${ }^{58}$. В кінці XVI ст. село утримував син Бартоломея Станіслав ${ }^{59}$.

Повертаючись до Завіш, зауважимо, що донька Яна Завіши Барбара у 1465 р. вийшла заміж за холмського підкоморія Станіслава Тенчинського

${ }^{48}$ Szyszka J. Formowanie i organizacja dóbr monarszych... - S. 122.

49 Згідно тексту документа, села знаходилися у Галицькому повіті: villarum Chodorkowicze et Sÿenÿawa in districtu Haliciensi consistentiu[m] (4.I.1415; 5.III.1540; AGAD. - MK, sygn. 61, k. 140-142 v.; регест: MRPS. - Pars 4, vol. 3. - P. 145, nr 20156; s. 375, supplement nr 508).

${ }^{50}$ AGZ. - T. 14. - S. 69, nr 562 (14.XII.1442; nobil. Stanislai de Smigrod); s. 366, nr 2799 (20.IV.1453; Nobil. Stanislaus de Chodorowstaw alias heres de Szmigrod).

${ }^{51}$ Boniecki A. Herbarz Polski. - Warszawa, 1900. - T. 3. - S. 31; AGZ. - T. 12. - S. 396, nr 4009 (1465).

${ }^{52}$ AGZ. - T. 14. - S. 134, nr 1090-1092 (23.V.1444; nr 1092: nobil. Stanislaum, Iohannem et Iurscham fratres de Zmigrod alias de Chodorowstaw).

${ }_{53}$ До згадок про Звенигород у джерелах XV ст. слід ставитися вкрай обережно - по перше, населений пункт $з$ такою ж назвою знаходиться неподалік Бучача; по друге, цей топонім часто записувався в документах як Zmigrod / Smigrod, аналогічно до села Жмігруд (а точніше двох сіл - Старий і Новий Жмігруд біля Ясла, з якими була пов'язана шляхетська родина Стадніцьких).

${ }^{54}$ AGZ. - T. 15. - S. 240, nr 1857 (1.IX.1486; gsum. Nicolaum Carnkowski heredem de Smygrod Subdfrm. Leopol.); s. 525, nr 4199 (30.IV.1484).

${ }_{55}^{55}$ Миколай Карнковський з Медухи та Букачівців займав уряди галицького мечника (14741481) і львівського підстолія (1483-1488). А. Бонецький пише, що він був також «галицьким воєводою» у 1456 p. (Urzędnicy województwa ruskiego... - S. 48, nr 138; s. 139, nr 1066; s. 346; Boniecki A. Herbarz Polski. - Warszawa, 1906. - T. 9. - S. 267-268).

${ }^{56}$ Молодший син Миколая Карнковського Тадеуш, який мав трьох синів, узагалі покинув Руське воєводство (Boniecki A. Herbarz Polski. - T. 9. - S. 267-268).

${ }^{57}$ Boniecki A. Herbarz Polski. - Warszawa, 1907. - T. 11. - S. 205; AGAD. - MK, sygn. 86, k. $24-26 \mathrm{v}$.

${ }^{58}$ ŹD. - Warszawa, 1902. - T. 18, cz. 1. - S. 70 (1578 p.).

${ }^{59}$ Boniecki A. Herbarz Polski. - T. 11. - S. 205. 
(† 1482 або 1484), а в 1486 р. - за Яна-Амора Тарновського (на момент шлюбу був краківським воєводою, з 1491 р. обіймав уряд краківського каштеляна), який і одідичив на початку XVI ст. Старосільську маєтність ${ }^{60}$.

За час володіння ключем Тарновськими окремі села в його складі передавалися в заставу. В 1537 р. син Яна і Барбари, теж краківський каштелян Ян записав галицькому підкоморію Яну Гологірському 2300 злотих на Старому Селі ${ }^{61}$, а в 1557 р. - 3200 злотих на Лопушній, Вільхівцю та Суходолі Габріелю Тарлу ${ }^{62}$.

Донька Яна Тарновського та його третьої дружини Зоф’ї Шидловецької Зоф'я - в 1553 р. вийшла заміж за князя Василя-Костянтина Острозького. В 1570 p. ${ }^{63}$ у його власності опинилося шість поселень загальною площею 116 ланів: Будьків (17 л.), Вільховець (8 л.), Глібовичі (26 л.), Гринів (20 л.) ${ }^{64}$, Лопушна (22 л.), Підмонастир (9 л.), Старе Село (25 л.), Суходіл (18 л.), Шоломия, або Шоломинь (17 л. $)^{65}$.

По смерті князя у 1608 р. комплекс відійшов до сина Януша, краківського каштеляна ${ }^{66}$. Його зусиллями усі володіння (24 міста та близько 600 сіл) Острозьких отримали статус ординації, тобто ставали неподільною цілістю. Януш помер у 1620 р., не залишивши по собі сина. Його єдина донька Євфросинія вийшла заміж за князя Олександра Заславського, у власність якого перейшла ординація разом з титулом князів Острозьких ${ }^{67}$.

Син Олександра Владислав-Домінік перебудував у 1642 р. оборонний замок у Старому Селі. У другому шлюбі з дочкою краківського каштеляна Катажиною Собеською (сестрою короля Яна III) в нього в 1650 р. народився син Олександр-Януш (прожив лише 22 роки). По смерті цього останнього по мечу представника роду Заславських спадок перейшов до його рідної сестри Теофілії, яка у 1671 р. стала дружиною польного коронного гетьмана князя Дмитра-Сжи Вишневецького, а в 1683 р. вдруге вийшла заміж за великого коронного маршалка Юзефа-Кароля Любомирського.

Матір Теофілії Катажина Заславська після смерті першого чоловіка (1656 р.) вийшла заміж за віленського воєводу князя Міхала Радзивіла

${ }^{60}$ Schneider A. Staresioło pod Lwowem. - S. 7.

${ }^{61}$ AGAD. - MK, sygn. 54, k. 221-221 v.; регест: MRPS. - Pars 4, vol. 3. - P. 71, nr 18825 (11 IX 1537).

${ }^{62}$ AGAD. - MK, sygn. 90, k. 149-151; регест: MRPS. - Pars 5, vol 1. - Varsoviae, 1919. P. 121, nr 1961 (13.I.1557).

${ }^{63}$ У 1567 р. помер без нащадків молодший брат Зоф’ї Ян-Кшиштоф, а в 1570 р. померла і вона сама. А. Шнайдер помилково називає Яна-Кшиштофа старшим сином гетьмана (народився у 1537-му, Зоф’я - в 1534 р.), див.: Schneider A. Staresioło pod Lwowem. - S. 9.

64 Гринів перейшов до рук кн. Острозьких від Коритків (а саме львівського писаря Бартоломея, згаданого тенутарієм Гринева у поборовому реєстрі 1552 р. (AGAD. - ASK, dział 1, sygn. 19, k. 401 v.).

65 ŹD. - Warszawa, 1902. - T. 18, cz. 1. - S. 76.

${ }^{66}$ Schneider A. Staresioło pod Lwowem. - S. 10.

${ }^{67}$ Ibid. - S. 11. 
(1658 р.). Подружжя посідало Старе Село до смерті Катажини (1694 р.), після чого Теофілія внесла маєтковий комплекс ${ }^{68}$ у склад володінь Любомирських ${ }^{69}$.

На мапі 2 можемо простежити, що впродовж XVIII ст. територія комплексу значно зросла за рахунок поселень на північному сході від нього. Основу цього територіального набутку складало давнє дідицтво родини Романовських-Свірзьких (села Городиславичі, Підгородище та Романів). Романовські походили від боярської родини Детьковичів ${ }^{70}-$ на це вказує ім'я Гліба (Йогана) Детьковича 3 Романова ${ }^{71}$, який, імовірно, був кровно спорідненим 3 іншими Детьковичами, згаданими в документах кінця XIV ст. (Василем ${ }^{72}$, Андрієм ${ }^{73}$ та «паном Детьком 3 Зубри $\left.{ }^{74} \gg\right)$. Не вдаючись детально в перелічення всіх представників родини Романовських, які володіли названими селами ${ }^{75}$, зауважимо лише, що після шлюбу в 1488 р. Беати Романовської з Пйотром Одновським Городиславичі, Підгородище та Романів перейшли у володіння Гербуртів ${ }^{76}$.

\footnotetext{
${ }^{68}$ Короткий період на початку XVIII ст. ключ перебував у власності Сенявських. Ельжбета Любомирська (донька великого коронного маршалка Станіслава-Геракліуша Любомирського) володіла ним спільно $з$ чоловіком, великим коронним гетьманом, краківським каштеляном Адамом-Миколаєм Сенявським (Schneider A. Staresioło pod Lwowem... - S. 14).

${ }^{69}$ Ibid. - S. 13-14.

${ }^{70}$ Szyszka J. Formowanie i organizacja dóbr monarszych... - S. 70.

${ }^{71}$ Katalog Niewodniczańskiego. - S. 16, nr 33 (6.XII.1396); s. 21, nr 46 (23.VI.1413); AGZ. Lwów, 1870. - T. 2 / [Oprac. O. Pietruski, X. Liske]. - S. 62, nr XXXVII; Розов В. Українські грамоти. - Київ, 1928. - Т. 1. - С. 81, № 44 (14.V.1412); AGAD. - MK, sygn. 61, k. 141 v. (4.I.1415).

${ }^{72}$ AGZ. - T. 2. - S. 15, nr IX (1378 p.).

${ }^{73}$ Ibid. - T. 8 / [Oprac. O. Pietruski, X. Liske]. - S. 20, nr XIII (10.XI.1378).

${ }^{74}$ Materiały historyczne // Przegląd Archeologiczny we Lwowie / Pod red. K. Widmanna. Lwów, 1882. - S. 72, nr 1.

${ }^{75}$ Історії родини Романовських-Свірзьких та їхніх володінь присвячені чотири підрозділи другого розділу дослідження польського історика Юзефа Відаєвича (Widajewicz J. Z przeszłości Buszcza: studjum historyczne. - Poznań, 1925. - S. 32-112). Зауважимо лише, що користуючись, в основному, матеріалами «Aktów grodzkich i ziemskich», на ряд питань автор книги все ж не дає відповідей. Так, залишається невідомим, хто такі: «Олюхна з Городиславич» (AGZ. - T. 14. - S. 61, nr 507 (12.X.1442; Oluchnam de Rodislawycze); s. 62, nr 509 (12.X.1442); s. $63, \mathrm{nr} 518,519,522$ (26.X.1442); s. 65, nr 534, 535 (9.XI.1442); s. 66, nr 542 (23.XI.1442)), «Стефан Осташевич Романовський з Городиславич» (9.VII.1451; Ibid. - S. 323, nr 2495: Stepan Ostaschewycz de Hrodyslawice domini Romanowski) та «Петро Мшуровський (Мсуровський) з Городиславич» (Ibid. - S. 31, nr 236 (7.IV.1441; nobil. Petrum Msurowsky de Rodzislauycze); s. 39, nr 315 (18.VIII.1441; nobil. Petri Mszurowsky de Hrodislauicze); s. 499, nr 3725 (1441). Невірно ідентифікована особа чоловіка Ядвіги Романовської (1.III.1471; Ibid. - T. 17. - S. 48, nr 521: Nobil. Iohannes Fedrouicz Kulcziski recognovit, quia nobili Heduigi Romanowska filie nobil. Iohannis Romanowski consorti sue sexcentos flor. dotis et alios sexcentos flor. dotalicii super medietatem omnium bonorum suorum assecurat). Мова йде не про Яна Федровича Кульчицького, а про Яна «Саса» Фредровича, сина Фредра з Плешевич (Przyboś K. Fredrowie herbu Bończa domus antiqui moris virtutisque cultrix // Rocznik Polskiego Towarzystwa Heraldycznego / Red. Stefan K. Kuczyński. - Warszawa, 1997. - Nowej serii t. 3 (14). - S. 84-86, 108). До того ж, Відаєвич у книзі чомусь називає Ядвігу Геленою (Widajewicz J. Z przeszłości Buszcza... - S. 79).

${ }^{76}$ Widajewicz J. Z przeszłości Buszcza... - S. 57, 97-98, 99; Cynarski S. Herburt Odnowski Mikołaj // PSB. - Wrocław-Warszawa-Kraków, 1961. - T. 9/3, zesz. 42. - S. 446; Łaszczyńska O. Herburt Piotr z Felsztyna, Boisk, Odnowa, zwany Odnowskim // Ibid. - S. 450.
} 
Син Пйотра - львівський староста і краківський воєвода Миколай не залишив потомства, тому передав володіння своїй сестрениці 77 Анні Чурилівні, дружині войницького (3 1553 р. сандомирського) каштеляна Станіслава Мацеєвського ${ }^{78}$. В другій половині XVI ст. селами Городиславичі, Підгородище та Романів володів руський воєвода Гієронім Сенявський ${ }^{79}$. В середині XVII ст. ці населені пункти разом із Селиськами, Підсосновом, Пліховом та Германовом складали комплекс власності його правнука - львівського старости Адама-Гієроніма Сенявського ${ }^{80}$.

77 Анна зі Стоянич Чурилівна-Мацеєвська була сестреницею львівського старости, донькою його сестри Катажини. Окрім того, вона доводилася сестрою Ельжбеті, дружині Якуба Гербурта. Миколай і Якуб Гербурти були далекими родичами (Boniecki A. Herbarz Polski. - Warszawa, 1901. - T. 4. - S. 35; Kowalska H. Maciejowski Stanisław // PSB. - Wrocław-Warszawa-KrakówGdańsk, 1974. - T. 19/1, zesz. 80. - S. 70; Malecki J. Herburt Jan // PSB. - Wrocław-Warszawa-Kraków, 1960-1961. - T. 9/3, zesz. 42. - S. 442; Cynarski S. Herburt Odnowski Mikołaj // Ibid. - S. 447).

В Коронній Метриці зберігаються маєткові транзакції Гербуртів і Мацеєвських, дотичні названих сіл і датовані 13 квітня 1553 р.:

1. передання Анною зі Стоянич, дружиною войницького каштеляна Станіслава Мацеєвського, в довічне володіння половини дідичних сіл (серед яких у Львівській землі Городиславичі, Підгороддя, Під’ярків, Романів та Яглуш) Яну, сину Якуба Гербурта 3 Фульштина та його дружини Ельжбети (рідної сестри Анни) (AGAD. - MK, sygn. 83, k. 231 v.-232 v.; регест: MRPS. - Pars 5, vol. 1. - Р. 99, nr 1564);

2. донація маєтностей Миколая Гербурта-Одновського (в т. ч. вищеназваних сіл) сестрениці Анні зі Стоянич (AGAD. - MK, sygn. 83, k. 233-234; регест: MRPS. - Pars 5, vol. 1. - P. 99, nr 1565);

3. надання в пожиттєву оренду Анною зі Стоянич поселень (в т. ч. перелічених у першому документі) Миколаю Гербурту-Одновському (AGAD. - MK, sygn. 83, k. 234-235; регест: MRPS. - Pars 5, vol. 1. - P. 99, nr 1566).

Керуючись документами, можемо припустити що після смерті Миколая Гербурта в 1555 р. Анна продовжувала володіти селами Городиславичі, Підгороддя, Під’ярків, Романів та Яглуш разом зі своїм чоловіком Станіславом Мацеєвським, а по смерті останнього в 1563 р. самостійно. Оскільки нам не вдалося відшукати у джерелах згадки про володіння названими селами племінником Анни, Яном Гербуртом, припускаємо, що він втратив це право.

${ }^{78}$ Cynarski S. Herburt Odnowski Mikołaj // PSB. - Wrocław-Warszawa-Kraków, 1960-1961. T. 9/3, zesz. 42. - S. 446-447.

${ }^{79}$ Нам не вдалося точно встановити, за яких обставин дідицтво Мацеєвських перейшло до руського воєводи Гієроніма Сенявського. Вдова Станіслава Анна вже не виходила заміж, а ії син Каспер не виступає у джерелах власником Романова та сусідніх сіл. Можливо, Сенявський отримав їх в якості посагу від своєї третьої дружини, також Анни, доньки люблінського старости Миколая Мацеєвського. Гієронім одружився з нею 2 березня 1573 р., вже через рік 18 червня 1574 р. - Анна померла, їх спільний син Єжи прожив лише 5 днів. Войницький каштелян Станіслав (чоловік Анни Чурилівни і власник Романова) та люблінський воєвода Миколай (тесть Сенявського) були близькими родичами (батько Станіслава, люблінський каштелян Бернард, та батько Миколая, сандомирський стольник Каспер - рідні брати). Іншими словами, ми припускаємо, що Анна Мацеєвська через певний час після смерті свого чоловіка, передала його двоюрідному брату право власності над Романовом і околицями. Той, у свою чергу, передав їх доньці Анні, а та - своєму чоловіку Гієроніму Сенявському (Kowalska H. Maciejowski Bernard // PSB. - Wrocław-Warszawa-Kraków-Gdańsk. - T. 19/1, zesz. 80. - S. 47; Kowalska H. Maciejowski Kasper// Ibid. - S. 58; Kaniewska I. Maciejowski Mikołaj // Ibid. - S. 62; Dworzaczek W. Maciejowski Samuel // Ibid. - S. 64; Plewczyński M. Sieniawski Hieronim // PSB. Warszawa-Kraków, 1996. - T. 37/1, zesz. 152. - S. 121).

${ }^{80}$ Про це свідчить колективний юрамент, складений 27 травня 1649 р. перед Львів- 
Села Водники і Пліхів (Пліхно, Плиска) всередині Старосільського ключа тривалий час належали до коронних маєтків, постійно перебуваючи в заставі ${ }^{81}$. 31540 по 1567 р. ними володіли Тарновські - краківський каштелян Ян ${ }^{82}$ і його донька Зоф’я ${ }^{83}$. Згідно інвентаря 1763 р. (про документ - нижче), села знову входили до досліджуваної маєтності.

Історію залюнення теренів Старосільського ключа слід розпочати 3 Черепова (Черепниська) - великого поселення, на базі котрого, на думку А. Шнайдера, виникли три села - Черепин, Давидів і Старе Село ${ }^{84}$ В 1415 р.

ським гродським судом представниками знищених татарським нападом сіл у власності Сенявського. Згідно документу, присягнули: Мартин Лециків з Романова, Іван Немців з Підгородища, Сенько Медулин з Селиськ та Ваньківців, Гриць Карпів з Городиславич, Іван Волков 3 Під’яркова, Луць Козаков з Підсоснова, Лучка Кавака з Германова (Жерела до істориї України-Руси. - Львів, 1901. - Т. 5.2 / Під ред. С. Томашівського. - С. 243-244, № 390).

${ }^{81}$ Осіб, які утримували у заставі перелічені села до 1567 р. називає Януш Шишка - це були Йов Сокольницький, Ян Дідушицький, Ян, Пйотр, Бартоломей та Рафал Коритки i дружина останнього Зоф'я з дому Шарамунських (Szyszka J. Formowanie i organizacja dóbr monarszych... - S. 261-262; AGAD. - MK, sygn. 24, k. 358 v. (15.XI.1510; регест: MRPS. Pars 4, vol. 2. - P. 75, nr 9741); MK, sygn. 25, k. 34 (16.IV.1511; perecr: MRPS. - Pars 4, vol. 1. - P. 67, nr 1134); MK, sygn. 33, s. 819 (14.VI.1520; регест: MRPS. - Pars 4, vol. 2. - P. 229, nr 12616); MK, sygn. 35, s. 821 (15.VII.1522; регест: MRPS. - Pars 4, vol. 2. - P. 284, nr 13265); MK, sygn. 36, s. 632-633 (15.IV.1524; perect: MRPS. - Pars 4, vol. 2. - P. 297, nr 13891); MK, sygn. 39, s. 282284 (27.III.1525; perест: MRPS. - Pars 4, vol. 2. - P. 313, nr 14200); AGAD. - MK, sygn. 43, s. 38-39 [k. 19 v.-20] (8.VIII.1527; регест: MRPS. - Pars 4, vol. 2. - P. 363, nr 15279). У кінці XVI - на початку XVIII ст. Відники з Пліховом утримували: Анджей Болек і його дружина Анна $з$ Пйотрковіц (25.VIII.1595; ЦДІАЛ. - Ф. 9, оп. 1, спр. 394, с. 1518-1519; регест: AGZ. - Т. 10. - S. 173, nr 2695); Адам Калиновський (18.XII.1620; ЦДІАЛ. - Ф. 9, оп. 1, спр. 374, с. 947; регест: AGZ. - Т. 10. - S. 210, nr 3345); Габріель Сільніцький (з дружиною Анною з Заклічина), як львівський ловчий (20.VIII.1660, 4.II.1662; Lustracja województwa ruskiego 1661-1665. - Wrocław, 1974. - Cz. 2 / Wyd. E. i K. Arłamowscy. - S. 21), і як каменецький каштелян (11.ІІІ.1679; ЦДІАЛ. - Ф. 9, оп. 1, спр. 439, с. 444-446; регест: AGZ. - Т. 10. - S. 340, nr 5671); Станіслав Щука (8.Х.1690; ЦДІАЛ. - Ф. 9, оп. 1, спр. 458, с. 2075-2077; регест: AGZ. - T. 10. - S. 362, nr 6079); полковник Кшиштоф Гондорф і дружина Кристина (з дому Курчів) - попередніми власниками були Антоній і Радзиня Щуки (20.VII.1699; ЦДІАЛ. - Ф. 9 , оп. 1, спр. 478, с. 1407-1409; регест: AGZ. - T. 10. - S. 378, nr 6354); капітан королівського регіменту Сжи Гондорф (19.IX.1718; ЦДІАЛ. - Ф. 9, оп. 1, спр. 194, с. 980-981; регест: AGZ. T. 10. - S. 402, nr 6787).

82 Ян Тарновський викупив їх у Рафала, Бартоломея та Пйотра з Коритків у лютому 1540 р., в березні - отримав право пожиттєвого володіння над ними (разом 3 королівським селом Гаї, яке перейшло до Тарновських від буського судді Пйотра Голдача), у червні - дідичного (AGAD. - MK, sygn. 57, k. 198 v.-199 (регест: MRPS. - Pars 4, vol. 1. - P. 390, nr 6729; 12.II.1540); AGAD. - MK, sygn. 57, k. 201-202 (регест: MRPS. - Pars 4, vol. 1. - P. 394, nr 6789; 22.III.1540); AGAD. - MK, sygn. 62, k. 58 v.-61 (регест: MRPS. - Pars 4, vol. 3. - P. 156, nr 20371; 26.VI.1540)).

${ }^{83}$ В 1567 р. Зоф'я передала Відники та Пліхів перемишльському підкоморію Яну Гербурту (AGAD. - MK, sygn. 100, k. 343-343 v. (регест: MRPS. - Pars 5, vol. 2. - Warszawa, 1961. P. 228, nr 9957; 20.VI.1567).

${ }^{84}$ Специфічна риса середньовічного оселення західноукраїнських земель полягала в тому, що давнє село не обов'язково складалося з єдиної суцільної території забудови. Поселення могло бути сформоване з низки дворищ, розкиданих на достатньо значних відстанях. При 

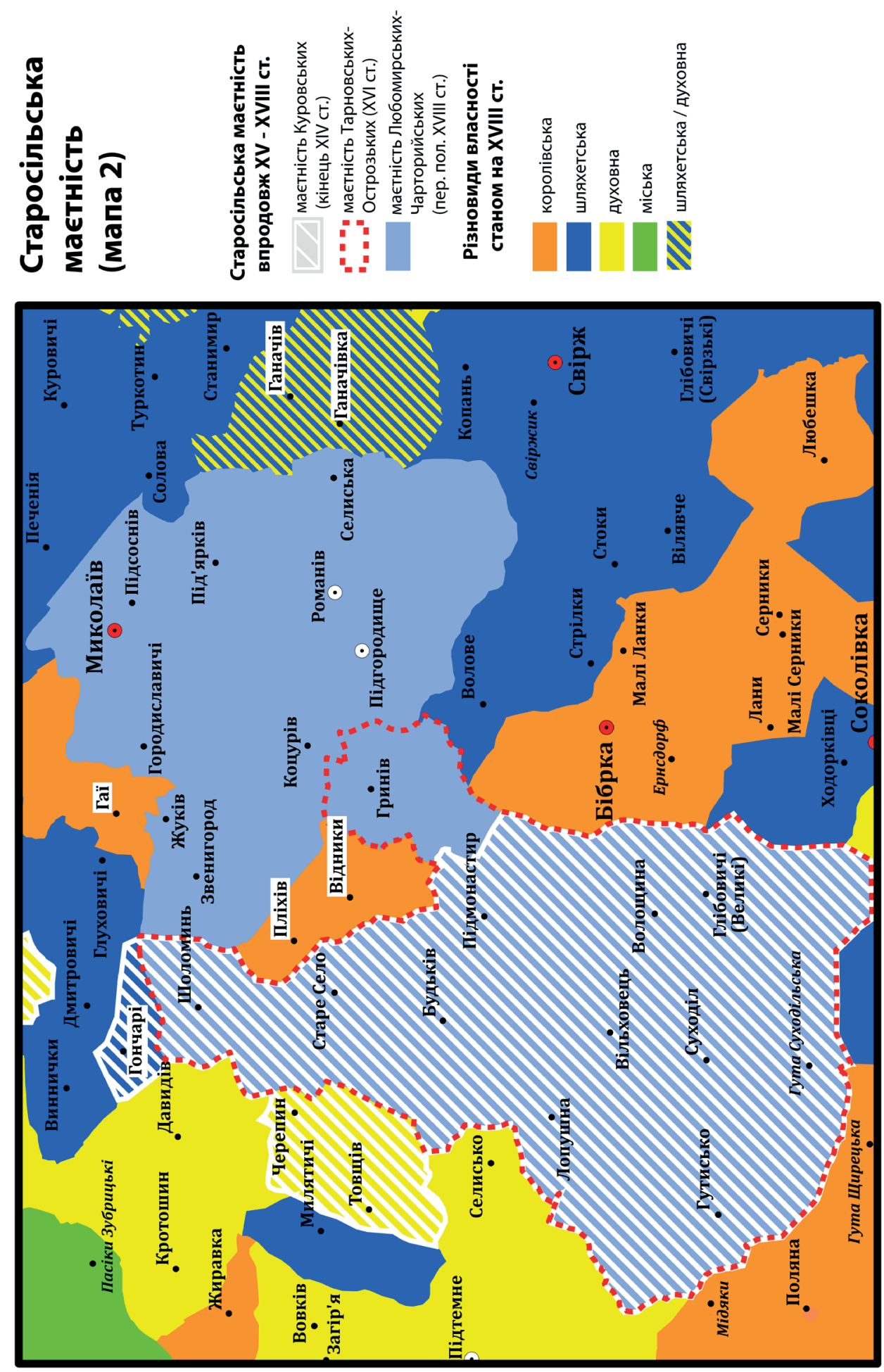
Пйотр з Курова надав останньому німецьке право ${ }^{85}$. Тим не менше, актові матеріали пізнішого часу згадують про тивунів у населених пунктах маєтності та околиць (Якуб зі Звенигорода ${ }^{86}$, Гринь з Будькова ${ }^{87}$, Климент 3 Під’яркова ${ }^{88}$, Гліб з Відник ${ }^{89}$, Іван з Романова $\left.{ }^{90}\right)$.

\section{Таблиця 1. Населені пункти Старосільського маєткового комплексу} та перші згадки про них у джерелах

\begin{tabular}{|l|c|l|}
\hline \multicolumn{1}{|c|}{$\begin{array}{c}\text { Населений } \\
\text { пункт }\end{array}$} & $\begin{array}{c}\text { Дата першої } \\
\text { згадки }\end{array}$ & \multicolumn{1}{c|}{ Джерело першої згадки } \\
\hline Будьків & 5 IV 1396 & Katalog Niewodniczańskiego. - S. 17, nr 35. \\
\hline Ваньківці & 1649 & $\begin{array}{l}\text { Жерела до істориї України-Руси. - Львів, 1901. - Т. 5.2 / } \\
\text { Під ред. С. Томашівського. - С. 244. }\end{array}$ \\
\hline Відники & 27 IX 1389 & ZDM. - T. 6. - S. 67, nr 1560. \\
\hline Вільховець & 1510 & AGAD. - ASK, dział 1, sygn. 20, k. 171. \\
\hline Волощина & 1696 & ЦДIAЛ. - Ф. 10, oп. 1, cпр. 118, c. 137. \\
\hline Гаї & 31 X 1391 & $\begin{array}{l}\text { Materiały archiwalne, wyjęte głównie z Metryki Litewskiej } \\
\text { od 1348 do 1605 roku / Wyd. A. Prochaska. - Lwów, 1890. - } \\
\text { S. 6, nr 9. }\end{array}$ \\
\hline Глібовичi & 5 IV 1396 & Katalog Niewodniczańskiego. - S. 17, nr 35. \\
\hline Городиславичi & 23 VI 1413 & Katalog Niewodniczańskiego. - S. 21, nr 46. \\
\hline Гринів & 5 IV 1396 & Katalog Niewodniczańskiego. - S. 17, nr 35. \\
\hline
\end{tabular}

цьому окрему назву мали як загалом весь населений пункт, так і окремі дворища у ньому. Останні з часом виокремлювалися в повноцінні села. Інша справа, що в актових документах писарі оперували занадто вузькою термінологією (villa, curia, area), щоб окреслити такі специфічні поселенські форми. Детальніше про це див.: Szyszka J. Formowanie i organizacja dóbr monarszych... - S. 31-32).

${ }^{85}$ Німецьке право отримували шість сіл у володінні Пйотра (Старе Село, Кухничі, Будьків, Підмонастир, Дубовичі та Глібовичі), об’єднаних спільною назвою - Старе Село. Це дозволяє припустити, що перелічені поселення виокремилися зі складу єдиного «давнього» Старого Села, яке у свою чергу виникло на базі давнього Черепова. Відтак, припущення А. Шнайдера можемо скоригувати таким чином: на основі Черепова виокремилося не три, а щонайменше вісім населених пунктів. В 1415 р. відбувся процес, зворотній вищеозначеному - об'єднання (нехай і формальне) повноцінних сіл в одне (відстань між найвіддаленішими «дворищами» у ньому - «новим» Старим Селом та Глібовичами складає 8,5 км по прямій і 12 км по течії р. Давидівки, вздовж якої були розташовані усі названі в документі 1415 р. села-дворища). За 150 гривень львівський міщанин Ганко ставав солтисом «нового» Старого Села, отримуючи у володіння 6 ланів, право зведення млинів, корчем, кузень, встановлення бортів та ремісничих яток (шевських, різничих, суконних, рибних), копання саджавок (невеликих ставків для розведення риби) (31.V.1415; Katalog Niewodniczańskiego. - S. 22, nr 47).

${ }^{86}$ AGZ. - T. 14. - S. 95, nr 748 (17.V.1443; Iacobus Thywn de Smigrod nobilis Iurscha de Chodorowstaw).

${ }^{87}$ Ibid. - T. 15. - S. 106, nr 759 (27.VII.1470; Hryn Tywn suus de Budkow).

${ }^{88}$ Ibid. - T. 14. - S. 446, nr 3353 (30.V.1455); s. 446, nr 3354 (30.V.1455; Clemens Thywn de Podyarkow).

${ }^{89}$ Ibid. - S. 130, nr 1055 (17.IV.1444).

${ }^{90}$ Ibid. - T. 15. - S. 483, nr 3801 (1476; homine Ty[wno] ipsius Stephani nomine Ivan), nr 3803 (1475; homine ipsius Stephani Ivan de Romanow ac Tywno); t. 19. - S. 518, nr 2883 (1475; cum homine ac tywno tuo Iwan de Romanow). 


\begin{tabular}{|c|c|c|}
\hline $\begin{array}{l}\text { Гута } \\
\text { Суходільська }\end{array}$ & 1785 & $\begin{array}{l}\text { Йосифінська (1785-1788) і Францисканська (1819-1820) } \\
\text { метрики. Перші поземельні кадастри Галичини. Покаж- } \\
\text { чик населених пунктів / Відп. ред. П. Захарчишина. - } \\
\text { Київ, 1965. - С. } 94 .\end{array}$ \\
\hline $\begin{array}{l}\text { Гутисько } \\
\text { Суходільське }\end{array}$ & 1763 & AGAD. - Archiwum Potockich z Lańcuta, sygn. 43/1, k. 53v. \\
\hline Дубівці & 5 IV 1396 & Katalog Niewodniczańskiego. - S. 17, nr 35. \\
\hline Жуків & 1515 & AGAD. - MK, sygn. 86, k. 24. \\
\hline Звенигород & 1086 & $\begin{array}{l}\text { Полное собрание русских летописей, изданное по высо- } \\
\text { чайшему повелению Археографическою комиссиею. - } \\
\text { Санкт-Петербург, 1846. - Т. 1.- С. } 88 .\end{array}$ \\
\hline Коцурів & 9 III 1410 & AGAD. - MK, sygn. 46, k. 28. \\
\hline Краслинчичі & $19 \mathrm{~V} 1452$ & AGZ. - T. 14. - S. 505, nr 3759. \\
\hline Кухничі & $31 \mathrm{~V} 141591$ & Katalog Niewodniczańskiego. - S. 22, nr 47. \\
\hline Лопушна & 5 IV 1396 & Katalog Niewodniczańskiego. - S. 17, nr 35. \\
\hline Миколаїв & 25 I 1670 & ЦДІАЛ. - Ф. 181, оп. 2, спр. 3119, арк. 1. \\
\hline Під’ярків & 29 VI 1368 & AGAD. - MK, sygn. 99, k. 187. \\
\hline Підгородище & 15 VIII 1397 & $\begin{array}{l}\text { Szyszka J. Formowanie i organizacja dóbr monarszych... - } \\
\text { S. } 342 .- \text { T. 14. - S. 141, nr } 1145 .\end{array}$ \\
\hline Підмонастир & 5 IV 1396 & Katalog Niewodniczańskiego. - S. 17, nr 35. \\
\hline Підсоснів & 29 VI 1368 & AGAD. - MK, sygn. 99, k. 187. \\
\hline Пліхів & 13 III 143992 & ZDM. - T. 8. - S. 37, nr 2208. \\
\hline Романів & 1 VI 1410 & AGZ. - T. 2. - S. 62, nr XXXVII. \\
\hline Селиська & $6 \mathrm{VI} 1455$ & AGZ. - T. 14. - S. 447, nr 3358. \\
\hline Старе Село & 5 IV 1396 & Katalog Niewodniczańskiego. - S. 17, nr 35. \\
\hline Суходіл & 5 IV 1396 & Katalog Niewodniczańskiego. - S. 17, nr 35. \\
\hline Шоломия & 27 VII 1386 & Розов В. Українські грамоти. - Київ, 1928. - Т. 1. - С. 31, № 16. \\
\hline
\end{tabular}

Більшість населених пунктів маєтності (як тих, що перебували у володінні Завіш, так і набутих пізніше) належать до давніх локацій. Перші згадки про них зустрічаємо в джерелах, головним чином, кінця XIV-XV ст. (див. таблицю 1). В документах з початку XVI ст. фіксується Вільховець, локований в опільських лісах неподалік річки Селисько (інша назва - Суходільський потік). XVII-м століттям датуються перші згадки про Ваньківці - невеликий присілок між Під’ярковом і Селиськами, та про Волощину - село на північ від Глібович на р. Давидівці.

Вирубка лісів з метою пошуку нових угідь для землеробства та промислів спонукала до закладення нових (виробничих - судячи з їх назв) поселень в масиві Львівського Опілля. В інвентарі 1763 р. вперше згадане село

91 Можливо, Кухничі і Княгиничі $з$ надання 1399 р. - одне й те ж село (Katalog Niewodniczańskiego. - S. 16-17, nr 35).

${ }_{92}$ Можливо, Пліхів згаданий ще раніше, а саме 27 вересня 1389 р. під назвою Poluchow (за іншою версією - це село Великий Полюхів): villas et haereditates Wyznany, Poluchow, Wodniky, Jarilowiczy et Synawa in districtu nostro Lemburgensi situatas (ZDM. - Cz. 6. - S. 67-68, nr 1560). 
Гутисько (Суходільське), яке виникло у верхів'ях Басарового потоку (в результаті часткового викорчовування однойменного лісу). Мешкали у ньому виключно поляки. У місці впадіння потоку до р. Селисько Йосифінська метрика зафіксувала Гуту Суходільську (див. таблицю 1).

Міські осередки на території Старосільського ключа. До моменту інкорпорації земель Галицько-Волинської держави у склад Польського королівства Звенигород остаточно втратив своє політичне значення ${ }^{93}$. В епоху Речі Посполитої магдебурзького права він не отримав. За твердженням А. Шнайдера, занепад Звенигорода спонукав Яна Завішу локувати нове місто, де в майбутньому планувалося звести замок. У 1448 р. сюди нібито були переселені мешканці Сондеччини (де, нагадаємо, розташовані села Рожнув і Грудек, продані у 1425-1426 рр. Куровськими Завішам), а ще через 6 років в новоствореному містечку (названому Гарбів) було фундовано римо-католицьку парафію ${ }^{94}$. Щоправда, жодних документів, які б підтверджували тези дослідника, відшукати не вдалося. В 1454 р. у Старому Селі справді було фундовано костел (детальніше про це нижче), однак акт закладення парафії не супроводжувався жодним наданням магдебурзького права Старому Селу.

Свого часу міський статус отримали села Підгороддя (Підгородище) i Романів, які з XVIII ст. увійшли до складу Старосільського ключа. Однак в якості міських осередків вони перебували нетривалий час. Підгороддя було локоване в 1509 р. Пйотром Гербуртом-Одновським ${ }^{95}$. Жоден 3 поборових

\footnotetext{
${ }^{93}$ На думку Я. Шишки, в княжий період Звенигород був центром волості, яка з ростом ролі Львова поступово увійшла до складу Львівської волості. Намагаючись відтворити її первісні кордони, дослідник, опираючись на перші згадки у джерелах про Бібрку (населений пункт на схід від Старого Села і Звенигорода) як міський осередок (1433 р.), і як центр римо-католицької парафії (1437р. - Шишка зазначає 1438 р.), а також, вочевидь, на документи, де Бібрка фігурує центром територіального комплексу з п’яти сіл у верхів'ях р. Боберки (Стара Бібрка, Волове, Серники, Лани, П'ятничани), припускає, що міська локація Бібрки вже тоді мала на меті оформити названі поселення в єдину територіальну цілість і був це той «залишок» Звенигородської волості, який станом на першу половину XV ст. ще утримувався у королівському домені. Зі свого боку можемо припустити, що це був найсхідніший «уламок» давньої волості (Szyszka J. Formowanie i organizacja dóbr monarszych... - S. 63, 67, 160; Badecki K. Zaginione księgi średniowiecznego Lwowa: studium rekonstrukcyjne // Kwartalnik Historyczny. Lwów, 1927. - T. 41. - S. 558, nr 28; ZDM. - Cz. 7 / Wyd. S. Kuraś. - Wroclaw, 1975. - S. 380-381, nr 2116 (оригінал: Zakład Narodowy im. Ossolińskich we Wrocławiu. - Pergamin nr 2953; копії: AGAD. - MK, sygn. 82, k. 89 v.-91; ЦДІАЛ. - Ф. 9, оп. 1, спр. 351, s. 1059-1060; регест: AGZ. T. 10. - S. 4, nr 65).

${ }^{94}$ Schneider $A$. Staresioło pod Lwowem. - S. 7.

${ }^{95}$ AGAD. - MK, sygn. 23, k. 386-386 v. [s. 753-754] (13.XI.1509):

Podhrodzie.

In nomi[n]e Domini amen.

Ad perpetua[m] rei memoria[m].

Regnu[m] et quoru[m]uis principanciu[u]m autoritas quicquid pro meliori condic[i]on[e] et augmento subditaru[m] suorum ex munimencia sua concedit perpetuo duraturum, id ne labilitat[i] temporis momentanea intereat consueuit apicibus autenticarum litterarum mandare.
} 
реєстрів XVI ст. Львівської землі не зафіксував його серед міських поселень. Містечко Романів заклала згадана вище Анна Чурилівна зі Стоянич, на той момент вдова Станіслава Мацеєвського ${ }^{96}$.

В другій половині XVII ст. на території Старосільського ключа з’явилося містечко Миколаїв (згаданий в інвентарі 1670 р., тарифі шелязного податку 1700 p. ${ }^{97}$, а також в реєстрі шелязного і чопового 1748 p. $\left.{ }^{98}\right)$. Найімовірніше, його локатором був Миколай-Гієронім Сенявський (1645-1683). Оскільки нам невідомі документи, в яких було б зафіксовано село $з$ такою назвою у володінні Сенявських, ми припускаємо, що як і Миколаїв над Дністром (за-

Proinde nos Sigismundus etc. significamus etc., quia attentis fidelibus seruicys generosi Herborth Petri Hodnowski de Felstyn fidelis nostri dilecti. Quibus hoc bello Moldauico durante sese nobis hic Leopoli feliciter agentibus reddidet comendatu[m] p[ro]p[te]r[e]a nichil ad futu[r]a obsequia nostra et sucessoru[m] nostroru[m] prompciore[m] efficere cupientes, sibi et succesoribus suis de certa sciencia et speciali gra[tia] regys nostris ac de consilio consiliarioru[m] nostrorum de villa ipsius hereditaria nu[n]cupata Podhrodzye in terra Leopolien[si] consistente opidum denuo erigere, fundare et collocare admisimus et consensimus, admittimusque et consentimus, erigimus et fundamus $\mathrm{p}[\mathrm{rese}] \mathrm{ntibus}$ pro tanto $\mathrm{vt}$ frequencior hominu[m] copia illis confinat quo celerius hoc ipsum opidu[m] denuo collocetur pro eius meliori condicion[e] fora ann[u]alia duo vnum videlicet ad diem Sancti Vitti, aliud pro festo Sancte Elizabeth annis singulis septimanale vero feria tercia singulis septimanis instituimus et indiximus, indicimus et imponimus per $\mathrm{p}$ [rese]ntes absque, $\mathrm{t}[\mathrm{ame}] \mathrm{n}$ preiudicio aliarum ciuitatu[m] et opidoru[m] in terra predicta Leopolien[si] consistencia per mercatores et negociatores vndecunq[ue] venientes inibi tenenda et habenda dantes et concedentes quibuslibet mercatoribus, negociatoribus alysq[ue] om[n]ibus et singulis hominibus cuiuscunq[ue] status et condic[i]onis, more aliarum ciuitatum et opidorum Regni nostri facultate[m] et libertatem vndecunq[ue] ad predictum opidu[m] Podhrodzye pro diebus fororum eorund[em] annalium et septimanaliu[m] mercandi gra[tia] veniendi, in eod[em]q[ue] opido diebus fororum preces et merces cuiuscunq[ue] gene[r]is et maneriey fuerint exponendi, vendendi, emendi, negociandi, res pro rebus com[m]uttandi et cambiendi, aliaq[ue] mercature et negociacionis gene[r]a exercendi libere et secure sub nostra et successoru[m] nostrorum plena facultate redeundi nisi talis sunt, quos iura non tuentur.

Ex quibus co[n]sorcea fidedignorum merito denegantur tenore presen[t]em mediante. In cuius rei testimoniu[m] sigillum nostrum $\mathrm{p}[$ rese]ntibus est appensum.

Act[um] Leopoli feria tercia proxima post festum Sancti Martini, anno Domini millesimo quingentesimo nono, Regni vero nostri anno terc[i]o presentibus testibus quibus proxime supra.

Регест: MRPS. - Pars 4, vol. 1. - P. 52, nr 893.

${ }^{96}$ AGAD. - MK, sygn. 97, k. 34-34 v. (26.I.1563):

Erectio oppidi Romanow.

In nomi[n]e Dom[ini] amen etc.

Quia r[ati]o[ne]m haben[tes] meritor[um] magn[ifici] Stani[slai] Maczieiowski castellani Sandomirien[si], curiae n[ost]rae marschalci, Lubomlien[si], Zawichosten[si] cap[i]t[ane]i syncere nobis dilecti. Consentiend[um] et admittend[um] duximus, consentimusq[ue] et admittimus praesen[tibus] 1[itte]ris nostris, vt mag[nifi]ca coniunx ipsius Anna de Stoÿenicze posset valeatque de villa sua haered[ita]ria Romanow in terra Leopolien[si] sitt[a] oppid[um] eiusd[em] nomi[ni] $\mathrm{s}$ Romanow erigere atq[ue] fundari, vt autem hoc ipsum oppid[um] Romanow eo citius homines confluunt etc., ut sup[ra].

Fora annualia primu[m] pro feria secunda post dominicam Palmarum et secund[um] pro festo sanctae Margarethae septimanale autem vnum singulis ferÿs secundis celebran[di].

Pегест: MRPS. - Pars 5, vol. 1. - P. 162, nr 2766.

${ }^{97}$ ЦДІАЛ. - Ф. 9, оп. 1, спр. 477, с. 596.

${ }^{98}$ Там само. - Спр. 554, с. 1543. 
кладений в 1570 р. ${ }^{99}$ ), цей міський осередок також був локований на «сухому корені».

Число оброблюваних угідь та наявність об'сктів інфраструктури дають можливість з'ясувати поборові реєстри, зразки яких стосуються головним чином XVI ст. Також у таблицях 2 і 3 нами використані матеріали т. зв. «ретент» (чи «делят») за 1600-1609 рр. - переліків населених пунктів, власники котрих повинні були погасити заборгованість 3 поборового податку. В окремих зразках «ретент» зустрічаємо записи на зразок «Iuxta quietationis $1578 »{ }^{100}$ та «tenetur vero iux[ta] quietationis anni 1579 nec non anni 1581» ${ }^{101}$, що вказують на використання застарілих даних. Відтак, зазначені в цих документах відомості актуальні радше для кінця XVI ст.

Матеріали описово-статистичних джерел, вміщені у таблицю, дають змогу говорити про достатній розвиток інфраструктури маєтності - окрім широко розповсюджених млинів та корчем зустрічаємо чимало згадок про відповідні земельні угіддя корчмарів та мірошників. Не надто великі параметри ланів у селах (в середньому по 7,5 ланів на село; в другій половині XVI ст. знаходимо відомості про угіддя, виміряні в «плугах») тим не менше вказують на значну залюдненість сіл ключа (на 1 лан припадало в середньому 3 кметі, а не 2, як у Александра Яблоновського ${ }^{102}$ ) і розвинуте рільництво.

Таблиця 2. Угіддя та інфраструктура сіл Старосільської маєтності у першій половині XVI ст. (за матеріалами поборових ресстрів)

\begin{tabular}{|c|c|c|c|c|}
\hline Село & Лани & $\begin{array}{c}\text { Священик та } \\
\text { церква }\end{array}$ & Млин & Корчма \\
\hline Будьків & $\begin{array}{l}10(1515), \\
9(1532), 1 \\
(1540)\end{array}$ & $1(1532)$ & $\begin{array}{l}2 \text { ручних (1510, } \\
1511,1515), \\
2 \text { млини }(1517), \\
1 \text { ручний (1532, } \\
1540)\end{array}$ & $\begin{array}{l}\text { vectoria }(1510, \\
1515,1517,1532) \text {, } \\
1(1540)\end{array}$ \\
\hline
\end{tabular}

${ }^{99}$ ЦДІАЛ. - Спр. 337, с. $159-163$; спр. 399 , с. 1484 ; спр. 403 , с. 2056 ; ф. 10, оп. 1, спр. 22 , c. 9-15 (регест: AGZ. - T. 10. - S. 101, nr 1525).

${ }^{100}$ ЦДІАЛ. - Ф. 9, оп. 1, спр. 363, с. 944 (1607).

${ }^{101}$ Там само. - Спр. 355 , с. 1573 (1600).

102 Йдеться про коефіцієнти (середнє число осіб, які мешкали під одним дахом в залежності від соціального статусу очільника домогосподарства, його професії чи оброблюваного ним земельного наділу), що були запропоновані А. Яблоновським для обчислення людності Волині та Поділля в другій половині XVI ст.: 1 лан, «плуг» = 12 осіб, 1 кметь, мельник, корчмар, рудник, «товариш» рудні, фолюш, коло дідичного млина, коло рудні, горілчаний котел = 6 осіб, 1 священик чи церква = 12 осіб (2 родини по 6 осіб - священика і дяка), 1 загородник, комірник, ремісник $=4$ особи, 1 коло млина $=3$ особи. Цими коефіцієнтами послуговуємось у своїх обчисленнях і ми - за винятком визначення кількості осіб за ланами та «плугами»; детальніше - у коментарях до табл. 3 (ŹD. - Warszawa, 1889. - T. 19 / [Wyd. A. Jabłonowski]. S. 33-36). 
Острозька давнина. Buп. 6

\begin{tabular}{|c|c|c|c|c|}
\hline Вільховець & \begin{tabular}{|l|}
$10(1515), 8.5$ \\
$(1532), 6.5$ \\
$(1540)$ \\
\end{tabular} & - & - & - \\
\hline $\begin{array}{l}\text { Глібовичі } \\
\text { (а також } \\
\text { Дубівці) }\end{array}$ & $\begin{array}{l}14 \text { (1515), } 24 \\
(1517), 16 \\
+7 \text { пустих } \\
(1532), 14 \\
(1540)\end{array}$ & $1(1532,1540)$ & $\begin{array}{l}\text { вальник }(1510, \\
1511,1515,1517, \\
1532), \text { ручний } \\
(1540)\end{array}$ & $\begin{array}{l}\text { brazeatoria }(1515, \\
1517), \text { vectoria } \\
(1510,1511), 2 \\
\text { vectoria }(1532), 1 \\
(1540) \\
\end{array}$ \\
\hline Гринів & $\begin{array}{l}8(1515,1517, \\
1532,1540), \\
\text { ще } 2 \text { пустих } \\
(1515)\end{array}$ & $\begin{array}{l}1(1511,1515,1517, \\
1532,1540)\end{array}$ & - & $\begin{array}{l}\text { vectoria }(1510, \\
1511,1515,1517, \\
1532), 1(1540)\end{array}$ \\
\hline Лопушна & \begin{tabular}{|l|}
6103 або \\
11104 (1515), \\
$10(1517), 6.5$ \\
$(1532,1540)$, \\
ще 2.5 пусті \\
$(1532)$ \\
\end{tabular} & $\begin{array}{l}1(1515,1532, \\
1540)\end{array}$ & $\begin{array}{l}\text { ручний }(1510, \\
1515,1517,1540), \\
\text { млин }(1511), \text { спу- } \\
\text { стошений (1532) }\end{array}$ & $\begin{array}{l}\text { brazeatoria }(1515, \\
1532), \text { vectoria } \\
(1510,1511), \\
\text { корчма }(1517), \\
\text { haereditaria }(1540)\end{array}$ \\
\hline $\begin{array}{l}\text { Монастир } \\
\text { (Підмонас- } \\
\text { тир) }\end{array}$ & $\begin{array}{l}8(1515), 6 \\
+0.5 \text { пусті } \\
(1532), 5 \\
(1540)\end{array}$ & $\begin{array}{l}1(1511,1515,1517, \\
1532)\end{array}$ & - & $\begin{array}{l}\text { brazeatoria (1515, } \\
1532), \text { vectoria } \\
(1510,1511), \\
\text { корчма (1517), } \\
\text { haereditaria }(1540)\end{array}$ \\
\hline Старе Село & $\begin{array}{l}18(1515, \\
1517) \\
9.5+2.5 \\
\text { пусті }(1532) \\
9(1540) \\
\end{array}$ & $\begin{array}{l}1(1511,1515,1517, \\
1532)\end{array}$ & $\begin{array}{l}\text { ручний (1532, } \\
1540)\end{array}$ & $\begin{array}{l}\text { brazeatoria }(1515, \\
1517), \text { vectoria } \\
(1510,1511,1532), \\
1(1540)\end{array}$ \\
\hline Суходіл & $\begin{array}{l}10(1515), 8 \\
(1532,1540), \\
\text { ще } 3 \text { пустих } \\
(1532)\end{array}$ & $\begin{array}{l}1(1515,1517,1532, \\
1540)\end{array}$ & $\begin{array}{l}\text { ручний }(1510,1511, \\
1515,1517,1532, \\
1540)\end{array}$ & $\begin{array}{l}\text { vectoria }(1510, \\
1511,1515,1532), \\
\text { brazeatoria }(1517), \\
1(1540)\end{array}$ \\
\hline Шоломинь & $\begin{array}{l}7(1515, \\
1517), 5.5 \\
+2.5 \text { пусті } \\
(1532), 6 \\
(1540)\end{array}$ & $\begin{array}{l}1(1515,1517,1532, \\
1540)\end{array}$ & - & $\begin{array}{l}\text { brazeatoria }(1515, \\
1517) \text {, vectoria } \\
(1510,1511,1532), \\
1(1540)\end{array}$ \\
\hline
\end{tabular}

\section{Примітки:}

1510 - AGAD. - ASK, dział 1, sygn. 20, k. 170 v.-171 (Дубівці згадані окремо).

1511 - Ibid. - K. 380-380 v. (Дубівці згадані разом з Шоломинню).

1511 - Ibid. - K. 468-468 v. (усі кількісні параметри вказані сумарно: mol[endina] $\mathrm{h}$ [aeredita]ria valnyky, quarta molendina manuali, quinque popones).

${ }^{103}$ ŹD. - Warszawa, 1902. - T. 18, cz. 1. - S. 155.

${ }^{104}$ AGAD. - ASK, dział 1, sygn. 20, k. 253. 
1515 - AGAD. - ASK, dział 1, sygn. 20, k. 253-253 v. (=ŹD. - Warszawa, 1902. - T. 18, cz. 1 / [Wyd. A. Jabłonowski]. - S. 155).

1517 - Ibid. - K. 609 v.-610.

1515 - Ibid, sygn. 17, k. 125 v.-126 v.

1540 - Ibid, k. 332.

Звенигород згаданий в реєстрах 1510, 1511, 1515 i 1517 рр. поруч з іншими поселеннями маєтності, хоча перебував у володінні родини Карнковських, а 31515 p. - Коритків. Лише в реєстрі 1511 р. про це є відповідна відмітка: Carnkowskÿ (Ibid, sygn. 20, k. 380 v.).

\section{Вжиті поняття:}

brazeatoria - корчма з власною броварнею.

vectoria - корчма, яка реалізовувала лише привізний алкоголь.

haereditaria - корчма у дідичному (спадковому) володінні.

\section{Таблиця 3. Угіддя, інфраструктура та мешканці сіл Старосільської} маєтності у другій половині XVI - на початку XVII ст.

(за матеріалами поборових ресстрів)

\begin{tabular}{|c|c|c|c|c|c|c|c|}
\hline Село & 1552 & 1567 & 1581 & 1589 & 1600 & 1601 & 1609 \\
\hline Будьків & $\begin{array}{l}16 \mathrm{k}+ \\
1 \operatorname{lnt}+1 \mathrm{p} \\
+\mathrm{mw}\end{array}$ & $\begin{array}{l}12 \ln + \\
0.25 \ln \mathrm{p}+ \\
4 \mathrm{~h}+1 \mathrm{p}+ \\
1 \mathrm{t}+2 \mathrm{~m} 2 \mathrm{rt}\end{array}$ & $\begin{array}{l}1 \operatorname{lng}+ \\
1 \ln + \\
1 \ln \mathrm{ln}+ \\
17 \mathrm{ar}+6 \mathrm{~h} \\
+(12+1) \\
\mathrm{i}+1 \mathrm{p}+ \\
\mathrm{mk} 2 \mathrm{rt}\end{array}$ & $\begin{array}{l}1 \operatorname{lnp}+1 \ln t+ \\
2 \ln m+17 \mathrm{ar} \\
+(0+6) \mathrm{h} \\
+(12+1) \mathrm{i} \\
+1 \mathrm{p}\end{array}$ & $\begin{array}{l}1 \ln p+ \\
2 \ln m+1 \ln \mathrm{t} \\
+17 \mathrm{ar}+ \\
(0+6) \mathrm{h}+ \\
(12+1) \mathrm{i}+ \\
1 \mathrm{p}+1 \mathrm{t}+ \\
\mathrm{m} 2 \mathrm{rt}\end{array}$ & $\begin{array}{l}1 \operatorname{lnp}+ \\
2 \operatorname{lnm}+1 \ln t \\
+17 \mathrm{ar}+(0 \\
+6) \mathrm{h}+(12 \\
+1) \mathrm{i}+1 \mathrm{p} \\
+1 \mathrm{t}+2 \mathrm{~m}\end{array}$ & $\begin{array}{l}9 \ln +6 h+ \\
(12+1) i+ \\
1 p+m k 2 r t\end{array}$ \\
\hline Вільховець & $8 k+1 p$ & $4 \ln$ & $\begin{array}{l}1 \operatorname{lnt}+8 \mathrm{ar} \\
+1 \mathrm{~h}\end{array}$ & $\begin{array}{l}1 \operatorname{lnm}+8 a r+ \\
(0+1) h\end{array}$ & $\begin{array}{l}1 \ln t+8 a r \\
+(0+1) h \\
+1 t\end{array}$ & $\begin{array}{l}1 \operatorname{lnt}+8 \mathrm{ar} \\
+(0+1) \mathrm{h} \\
+1 \mathrm{t}\end{array}$ & $4 \ln +1 h$ \\
\hline Глібовичі & $\begin{array}{l}60 \mathrm{k}+2 \mathrm{p} \\
+1 \operatorname{lnt}+ \\
\mathrm{mw}\end{array}$ & $\begin{array}{l}14 \ln + \\
0.5 \ln p+ \\
1 p+1 t+ \\
\text { m1rt }\end{array}$ & $\begin{array}{l}1 \operatorname{lnp}+ \\
56 \mathrm{ar}+7 \mathrm{~h} \\
+1 \mathrm{p}+1 \mathrm{v} \\
+(8+0) \\
\mathrm{i}+3 \mathrm{a}+ \\
\mathrm{mk} 1 \mathrm{rt}\end{array}$ & $\begin{array}{l}1 \ln p+56 a r \\
+7 \mathrm{~h}+(8+ \\
0) \mathrm{i}+1 \mathrm{p}+3 \mathrm{a} \\
+\mathrm{mk} 1 \mathrm{rt}\end{array}$ & $\begin{array}{l}1 \operatorname{lnt}+1 \ln p \\
+56 a r+7 h \\
+8 i+1 p+ \\
1 v+3 a+ \\
1 t+m k 1 r t\end{array}$ & $\begin{array}{l}1 \ln t+1 \ln p \\
+56 a r+6 h \\
+8 i+1 p+ \\
1 v+3 a+ \\
1 t+m k\end{array}$ & $\begin{array}{l}14 \ln +1 \ln p \\
+1 \ln t+7 \mathrm{~h} \\
+8 \mathrm{i}+1 \mathrm{p} \\
+3 \mathrm{a}+1 \mathrm{t}+ \\
\mathrm{mk}\end{array}$ \\
\hline Гринів & $\begin{array}{l}1 \operatorname{lnt}+ \\
18 \mathrm{k}\end{array}$ & $\begin{array}{l}8 \ln + \\
0.25 \ln p+ \\
5 h+1 p\end{array}$ & $\begin{array}{l}1 \operatorname{lnp}+ \\
1 \operatorname{lnt}+ \\
20 \mathrm{ar}+15 \mathrm{~h} \\
+(2+0) \mathrm{i} \\
+1 \mathrm{p}+1 \mathrm{a}\end{array}$ & $\begin{array}{l}1 \ln p+1 \ln m \\
+20 a r+(15 \\
+0) h+(2+ \\
0) i+1 p+1 a\end{array}$ & $\begin{array}{l}1 \ln p+1 \ln t \\
+20 a r+ \\
(15+0) h \\
+2 i+1 p+ \\
1 a+1 t\end{array}$ & $\begin{array}{l}1 \ln p+1 \ln t \\
+20 a r+ \\
(15+0) h \\
+2 i+1 p \\
+1 t\end{array}$ & $\begin{array}{l}6 \ln +1 \ln p \\
+0.5 \ln t+ \\
(15+0) h \\
+2 \mathrm{i}+1 \mathrm{p}+ \\
1 \mathrm{a}+1 \mathrm{t}\end{array}$ \\
\hline Лопушна & $\begin{array}{l}20 \mathrm{k}+ \\
\mathrm{mw}+ \\
1 \operatorname{lnt}+ \\
1 \mathrm{p}\end{array}$ & $\begin{array}{l}6 \ln + \\
0.25 \ln t+ \\
? \operatorname{lnp}+1 \mathrm{t}+ \\
\mathrm{mk} 1 \mathrm{rt}\end{array}$ & $\begin{array}{l}1 \operatorname{lnt}+ \\
22 \mathrm{ar}+6 \mathrm{~h} \\
+1 \mathrm{p}+ \\
\mathrm{mk} 1 \mathrm{rt}\end{array}$ & $\begin{array}{l}11 \mathrm{~nm}+22 \mathrm{ar} \\
+(6+0) \mathrm{h}+ \\
1 \mathrm{p}+\mathrm{mk} 1 \mathrm{rt}\end{array}$ & $\begin{array}{l}1 \ln p+1 \ln t \\
+22 a r+ \\
(6+0) h+ \\
1 p+1 t+ \\
m k 1 r t\end{array}$ & $\begin{array}{l}1 \operatorname{lnp}+1 \operatorname{lnt} \\
+22 \mathrm{ar}+(6 \\
+0) \mathrm{h}+1 \mathrm{p} \\
+1 \mathrm{t}+\mathrm{m} 1 \mathrm{rt}\end{array}$ & $\begin{array}{l}6 \ln +1 \ln t \\
+(6+0) h \\
+1 p+1 t+ \\
m k 1 r t\end{array}$ \\
\hline
\end{tabular}




\begin{tabular}{|c|c|c|c|c|c|c|c|}
\hline Підмонастир & $\begin{array}{l}10 \mathrm{k}+1 \mathrm{p} \\
+1 \operatorname{lnt}+ \\
\mathrm{mw}\end{array}$ & $\begin{array}{l}5 \ln + \\
0.25 \ln t+ \\
0.25 \ln \mathrm{p}+ \\
1 \mathrm{p}+1 \mathrm{a}+ \\
1 \mathrm{t}+\mathrm{mk} 1 \mathrm{rt}\end{array}$ & \begin{tabular}{|l}
$11 \ln +$ \\
$1 \operatorname{lnt}+$ \\
$11 \operatorname{lnm}+$ \\
$9 \mathrm{ar}+6 \mathrm{~h}+$ \\
$1 \mathrm{p}+1 \mathrm{a}+$ \\
$\mathrm{mk} 1 \mathrm{rt}$
\end{tabular} & $\begin{array}{l}1 \operatorname{lnp}+1 \operatorname{lnt}+ \\
9 \mathrm{ar}+(6+0) \\
\mathrm{h}+1 \mathrm{p}+1 \mathrm{a} \\
+\mathrm{m} 1 \mathrm{rt}\end{array}$ & $\begin{array}{l}1 \operatorname{lnp}+1 \operatorname{lnt} \\
+1 \operatorname{lnm}+ \\
9 \mathrm{ar}+(6+ \\
0) \mathrm{h}+1 \mathrm{p}+ \\
1 \mathrm{a}+1 \mathrm{t}+ \\
\mathrm{m} 1 \mathrm{rt}\end{array}$ & $\begin{array}{l}1 \operatorname{lnp}+1 \operatorname{lnt} \\
+1 \operatorname{lnm}+ \\
9 \mathrm{ar}+(5+ \\
0) \mathrm{h}+1 \mathrm{p}+ \\
1 \mathrm{a}+1 \mathrm{t}+ \\
\mathrm{m} 1 \mathrm{rt}\end{array}$ & $\begin{array}{l}6.5 \ln +(6 \\
+0) \mathrm{h}+ \\
1 \mathrm{p}+1 \mathrm{a}+ \\
\mathrm{mk} 1 \mathrm{rt}\end{array}$ \\
\hline Старе Село & $\begin{array}{l}20 \mathrm{k}+ \\
1 \operatorname{lnt}+2 \mathrm{p} \\
+\mathrm{mw}\end{array}$ & $\begin{array}{l}9 \ln + \\
0.5 \ln t+ \\
0.25 \ln p+ \\
4 \mathrm{~h}+1 \mathrm{p}+ \\
1 \mathrm{t}+\mathrm{mk} 1 \mathrm{rt}\end{array}$ & $\begin{array}{l}1 \operatorname{lnp}+1 \ln t \\
+25 a r+ \\
11 \mathrm{~h}+(15 \\
+0) \mathrm{i}+ \\
1 \mathrm{p}+1 \mathrm{v}+ \\
6 \mathrm{a}+2 \mathrm{t}+ \\
\mathrm{mk} 3 \mathrm{rt}\end{array}$ & $\begin{array}{l}1 \operatorname{lnp}+11 \mathrm{~nm} \\
+25 \mathrm{ar}+(0+ \\
11) \mathrm{h}+(15+ \\
0) \mathrm{i}+1 \mathrm{p}+1 \mathrm{v} \\
+6 \mathrm{a}+1 \mathrm{t}+ \\
\mathrm{mk3rt}\end{array}$ & $\begin{array}{l}1 \operatorname{lnp}+1 \operatorname{lnt} \\
+25 \mathrm{ar}+(0 \\
+11) \mathrm{h}+ \\
15 \mathrm{i}+1 \mathrm{p}+ \\
1 \mathrm{v}+6 \mathrm{a}+ \\
2 \mathrm{t}+\mathrm{mk} 3 \mathrm{rt}\end{array}$ & $\begin{array}{l}1 \operatorname{lnp}+1 \operatorname{lnt} \\
+25 \mathrm{ar}+(0 \\
+11) \mathrm{h}+ \\
15 \mathrm{i}+1 \mathrm{p}+ \\
1 \mathrm{v}+6 \mathrm{a}+ \\
2 \mathrm{t}+\mathrm{mk} 3 \mathrm{rt}\end{array}$ & $\begin{array}{l}9 \ln +1 \operatorname{lnt} \\
+? \mathrm{i}+1 \mathrm{p}+ \\
1 \mathrm{v}+2 \mathrm{t}+ \\
\mathrm{mk} 3 \mathrm{rt}\end{array}$ \\
\hline Суходіл & $\begin{array}{l}1 \operatorname{lnt}+ \\
22 \mathrm{k}+1 \mathrm{p} \\
+\mathrm{mw}\end{array}$ & $\begin{array}{l}7.5 \ln + \\
0.25 \ln t+ \\
1 \mathrm{p}+1 \mathrm{t}+ \\
\mathrm{mk} 1 \mathrm{rt}\end{array}$ & $\begin{array}{l}1 \operatorname{lnp}+1 \operatorname{lnt} \\
+18 \mathrm{ar}+ \\
2 \mathrm{~h}+(0+ \\
2) \mathrm{i}+1 \mathrm{p}+ \\
\mathrm{mk} 1 \mathrm{rt}\end{array}$ & $\begin{array}{l}1 \operatorname{lnp}+1 \ln m \\
+18 \mathrm{ar}+(2 \\
+0) \mathrm{h}+(0 \\
+2) \mathrm{i}+1 \mathrm{p}+ \\
\mathrm{mk} 1 \mathrm{rt}\end{array}$ & $\begin{array}{l}0.5 \ln t+ \\
0.5 \ln \mathrm{p}+ \\
12 \mathrm{ar}+1 \mathrm{p}+ \\
1 \mathrm{t}+(? \mathrm{~h}+ \\
? \mathrm{~m}) 105\end{array}$ & $\begin{array}{l}1 \operatorname{lnp}+1 \operatorname{lnt} \\
+15 \mathrm{ar}+(2 \\
+2) \mathrm{i}+1 \mathrm{p} \\
+1 \mathrm{t}+\mathrm{m} 1 \mathrm{rt}\end{array}$ & $\begin{array}{l}6 \ln +0.5 \ln t \\
+0.5 \ln p+ \\
(2+0) \mathrm{h}+ \\
2 \mathrm{i}+1 \mathrm{p}+1 \mathrm{t} \\
+\mathrm{mk} 1 \mathrm{rt}\end{array}$ \\
\hline Шоломинь & $\begin{array}{l}1 \operatorname{lnt}+ \\
22 \mathrm{k}+ \\
1 \mathrm{p}\end{array}$ & $\begin{array}{l}6 \ln + \\
0.25 \ln t+ \\
5 h+1 t\end{array}$ & $\begin{array}{l}1 \operatorname{lnp}+ \\
1 \operatorname{lnt}+1 \mathrm{p} \\
+17 \mathrm{ar}+ \\
13 \mathrm{~h}+(9 \\
+1) \mathrm{i}\end{array}$ & $\begin{array}{l}1 \operatorname{lnp}+1 \operatorname{lnm} \\
+1 \mathrm{p}+17 \mathrm{ar} \\
+(13+0) \mathrm{h} \\
+(9+1) \mathrm{i}\end{array}$ & $\begin{array}{l}1 \ln p+1 \operatorname{lnt} \\
+1 \mathrm{p}+17 \mathrm{ar} \\
+(13+0) \\
\mathrm{h}+(9+1) \\
\mathrm{i}+1 \mathrm{t}\end{array}$ & $\begin{array}{l}1 \operatorname{lnp}+1 \operatorname{lnt} \\
+1 \mathrm{p}+17 \mathrm{ar} \\
+(13+0) \\
\mathrm{h}+(9+1) \\
\mathrm{i}+1 \mathrm{t}\end{array}$ & $\begin{array}{l}6 \ln +1 ? \ln p \\
+1 ? \ln t+ \\
1 \mathrm{p}+(9+ \\
1) \mathrm{i}+1 \mathrm{t}\end{array}$ \\
\hline ВСЬОГО & $\begin{array}{l}196 \mathrm{k}, \\
8 \mathrm{lnt}, \\
6 \mathrm{mw}, \\
10 \mathrm{p}\end{array}$ & $\begin{array}{l}71.5 \ln , \\
1.5 \ln \mathrm{p}, \\
18 \mathrm{~h}, 6 \mathrm{p}, \\
7 \mathrm{t}, 3 \mathrm{~m} 3 \mathrm{rt} \\
+4 \mathrm{mk} 4 \mathrm{rt} \\
1.5 \operatorname{lnt}, 1 \mathrm{a}\end{array}$ & $\begin{array}{l}7 \operatorname{lnp}, 8 \operatorname{lnt}, \\
2 \operatorname{lnm}, \\
192 \mathrm{ar}, \\
67 \mathrm{~h}, \\
50 \mathrm{i}, 8 \mathrm{p}, \\
6 \mathrm{mk} 9 \mathrm{rt}, \\
2 \mathrm{v}, 2 \mathrm{t}, 11 \mathrm{a}\end{array}$ & $\begin{array}{l}\text { 7lnp, 21nt, } \\
8 \operatorname{lnm}, 192 \mathrm{ar}, \\
67 \mathrm{~h}, 50 \mathrm{i}, 8 \mathrm{p}, \\
11 \mathrm{a}, 4 \mathrm{mk} 6 \mathrm{rt} \\
+\mathrm{m} 1 \mathrm{rt}, 1 \mathrm{v}, \\
1 \mathrm{t}\end{array}$ & $\begin{array}{l}7.5 \ln \mathrm{p}, \\
3 \operatorname{lnm}, \\
186 \mathrm{ar}, 65 \mathrm{~h}, \\
48 \mathrm{i}, 8 \mathrm{p}, \\
2 \mathrm{~m} 3 \mathrm{rt}+ \\
3 \mathrm{mk} 5 \mathrm{rt}+ \\
? \mathrm{~m}, 8.5 \operatorname{lnt}, \\
10 \mathrm{t}, 2 \mathrm{v}, 11 \mathrm{a}\end{array}$ & $\begin{array}{l}8 \operatorname{lng}, 3 \operatorname{lnm}, \\
9 \operatorname{lnt}, 189 \mathrm{ar}, \\
63 \mathrm{~h}, 52 \mathrm{i}, \\
8 \mathrm{p}, 10 \mathrm{t}, \mathrm{mk} \\
+3 \mathrm{~m} 3 \mathrm{rt} \\
+\mathrm{mk} 3 \mathrm{rt}+ \\
2 \mathrm{~m}, 10 \mathrm{a}, \\
2 \mathrm{v}\end{array}$ & $\begin{array}{l}35 \mathrm{i}, 8 \mathrm{p}, \\
5 \mathrm{mk} 8 \mathrm{rt}+ \\
\mathrm{mk}, 43 \mathrm{~h}, \\
3.5 \ln \mathrm{p}, \\
5 \operatorname{lnt}, 5 \mathrm{a}, 7 \mathrm{t}, \\
1 \mathrm{v}, 66.5 \ln \end{array}$ \\
\hline
\end{tabular}

\section{Примітки:}

1552 - AGAD. - ASK, dział 1, sygn. 19, k. 170 v. (число кметів у с. Гринів і Шоломинь зазначене лише для тих частин поселень, що перебували в тенуті Пйотра Коритка; податок зібрано 13 (Шоломинь), 23 (Гринів), 25 (Підмонастир) серпня і 2 (Вільховець, Лопушна, Суходіл), 9 (Старе Село, Будьків), 15 (Глібовичі) вересня 1552 р.).

Окрім с. Гринів і Шоломинь, в тенуті Тарла ${ }^{106}$ перебували Вільховець, Лопушна, Підмонастир та Суходіл. Родині Тарновських додатково належало село Відники, яке вони ділили зі згаданим Пйотром Коритком (Ibid), а також Гаї, утримуване разом 3 неназваним Щуцьким (Ibid. -

${ }^{105}$ Поруч зазначено: tenetur vero iux[ta] quietationis anni 1579 nec non anni 1581 (ЦДІАЛ. Ф. 9, оп. 1, спр. 355, с. 1573).

${ }_{106}$ Можливо, йдеться про радомського каштеляна Габріеля Тарла, який отримав у 1557 p. черговий запис на Лопушні, Вільхівцю та Суходолі (13.I.1557; AGAD. - MK, sygn. 90, k. 149151; регест: MRPS. - Pars 5, vol. 1. - P. 121, nr 1961). 
К. 182 v.). У таблицю вони не внесені, оскільки були тимчасовими володіннями.

1567 - Ibid. - K. 400 v.-401 v. (податок зібрано 4 (Суходіл) і 29 (Глібовичі, Гринів) жовтня, 5 (Старе Село), 7 (Будьків), 17 (Шоломия, Вільховець, Лопушна) і 20 (Підмонастир) листопада 1567 р.).

В тенуті Павела Скотницького (з 1569 по 1590 р. галицького хорунжого ${ }^{107}$ ) перебували села Вільховець, Лопушна, Суходіл ${ }^{108}$, в тенуті невідомого Асмана (можливо, представника родини Аскманицьких (Яскманицьких) з Перемишльської землі) - село Глібовичі (Ibid. - K. 401 v.). Родині Тарновських додатково належали села Відники, Гаї і Серники (Ibid. К. 401). Вони не внесені у таблицю ${ }^{109}$.

1581 - Ibid. - K. 785 v.-786 v. (у рубриці «Комірники» вказані бідні комірники + комірники 3 худобою, замість священиків - церкви; у рубриці «Загородники» для с. Глібовичі вказано число загородників з земельними ділянками).

1589 - Ibid. - K. 885 v.-886 v. (у рубриці «Комірники» вказані бідні комірники + комірники 3 худобою, замість священиків - церкви; у рубриці «Загородники» вказані загородники + загородники на млині (hortulani ex triturione viventes), для с. Глібовичі вказано число загородників з земельними ділянками).

1600 - ЦДІАЛ. - Ф. 9, оп. 1, спр. 355, с. 1573-1574.

1601 - Там само. - Спр. 356, с. 795-797 (село Гринів помилково назване Villa Romanow).

1609 - Там само. - Спр. 365, с. 955-956.

Вжиті скорочення: a - artifex (ремісник), ar - aratura («плуг», міра площі), h - hortulanus (загородник), $\mathbf{i}$ - inquilinus (комірник), $\mathbf{k}-\mathrm{kmiec} /$ kmeth (кметь), ln - laneus (лан), lnm - laneus molendinatorialis (мірошницький лан), Inp - łan popowski, popowzczyzna (попівський лан, «попівщина»), Int - laneus tabernatorialis (корчмарський лан, «корчмарщина»), m - molendinum / młyn (млин), mk - młyn korzecznik (млин-коречник), mw - młyn-walnyk (млин-«вальник»), p - pop (піп), rt - rota (коло млина), $\mathbf{t}$ - tabernator (корчмар), v - vagus (гультяй).

${ }^{107}$ Urzędnicy województwa ruskiego... - S. 36, nr 14.

108 Павел Скотницький замінив Габріеля Тарла у 1560 p. (MRPS. - Pars 5, vol. 2. - P. 263, nr 8866).

109 У наступних поборових реєстрах власником села Відники зазначений Бартоломей Коритко (AGAD. - ASK, dział 1, sygn. 19, k. 785 (1581 p.), 885 (1589 p.)), села Гаї - Сжи Красіцький (ŹD. - Warszawa, 1902. - T. 18, cz. 1. - S. 67 (1578 p.)) і Венцеслав Слівніцький (AGAD. - ASK, dział 1, sygn. 19, k. 785 (1581 p.), 885 (1589 p.)), села Серники - Сжи Красіцький (ŹD. - Warszawa, 1902. - T. 18, cz. 1. - S. 67 (1578 p.); AGAD. - ASK, dział 1, sygn. 19, k. 792 (1581 p.), 894 v. (1589 p.)). 


\section{Обчислення:}

Кметі: 196 (1552 р.)

Кметівські лани: 71,5 (1567 р.), 61,5 (1609 р.). Середнє значення - 66,5 ланів. Відповідно, на 1 лан нараховуємо в середньому 3 кметі, а 3 родинами $3 * 6=18$ осіб.

«Плуги»: 192 (1581 і 1589 рр.), 186 (1600 р.), 189 (1601 р.). Середнє значення - 189 «плугів». Відповідно, 1 лану відповідає бл. 3 «плугів», а 1 «плугу» - 1 кметь.

«Попівщини» та священики: 1,5 лани і 6 священиків (1567р.), 7 ланів і 8 священиків (1581р.), 7 ланів і 8 священиків (1589р.), 7.5 ланів і 8 священиків (1600р.), 8 ланів і 8 священиків (1601р.), 3.5 лани і 8 священиків (1609 р.);

«Корчмарщини» і корчми: 8 ланів (1552 р.), 1.5 ланів і 7 корчем (1567 р.), 8 ланів і Z корчми (1581 р.), 2 лани і 4 корчма (1589 р.), 8.5 ланів і 10 корчем (1600 p.), 9 лапів і 10 корчем (1601 р.), 5 ланів і 7 корчем (1609 р.);

Мельницькі грунти і млини:

6 млинів «вальників» (1552 р.),

3 млини на 3 колах +4 млини «коречники» на 4 колах (1567 р.),

Z лани і 6 млинів «коречників» на 9 колах (1581р.),

8 ланів і 1 млин на 1 көлі 4 млини жкоречники》 на 6 көлах (1589 р.),

3 лани і 2 млини на 3 колах +3 млини «коречники» на 5 колах + млин (1600 p.),

3 лани і 3 млини на 3 колах + млин «коречник» на 3 колах +2 млини + млин «коречник» (1601р.), 5 млинів «коречників» на 8 колах + млин «коречник» (1609 р.).

Аби не дублювати дані, що стосуються кількості священиків, мельників та корчмарів параметрами їх землеволодінь, ми порівнювали їх між собою і нехтували меншими показниками (закреслені). Як бачимо, серед останніх частіше трапляються відомості про лани. Попри те, що на них могли мешкати селяни і обробляти грунти, ми все ж не знаємо, ані хто вони (кметі, загородники, комірники), ані їх числа - тому коефіцієнти по мірошницьких ланах, корчмарщинах і попівщинах прирівнюємо до коефіціентів по мельниках, корчмарях та священиках $(6,6$ і 12 відповідно)

Обчислення за млинами здійснюватимемо у два способи - за спорудами (з розрахунку -1 млин = 1 мельник (очільник домогосподарства, в якому разом 3 ним 6 осіб) і за колами (з розрахунку 3 особи на коло або на млин, де кількість кіл не зазначена).

1552: $196 \mathrm{k}^{*} 6+8 \operatorname{lnt} * 6+6 \mathrm{mw}^{*} 6+10 \mathrm{p} * 12=\mathbf{1 3 8 0}$ осіб;

1567: $71.5 \ln * 18+1.5 \operatorname{lnp}+18 \mathrm{~h} * 4+6 \mathrm{p} * 12+7 \mathrm{t} * 6+7 \mathrm{~m} * 6($ або $7 \mathrm{rt} * 3)+1.5 \operatorname{lnt}$ $+1 \mathrm{a} * 4=1519$ (або 1498 осіб); 
1581: $7 \operatorname{lnp}+8 \operatorname{lnt} * 6+2 \operatorname{lnm}+192 \mathrm{ar} * 6+67 \mathrm{~h} * 4+50 \mathrm{i} * 4+8 \mathrm{p} * 12+6 \mathrm{mk}^{*} 6$ (або $9 \mathrm{rt} * 3)+2 \mathrm{v} * 4+2 \mathrm{t}+11 \mathrm{a} * 4=\mathbf{1 8 5 2}$ (або 1843 особи);

1589: $7 \operatorname{lnp}+2 \operatorname{lnt} * 6+8 \operatorname{lnm} * 6+192 \mathrm{ar} * 6+67 \mathrm{~h} * 4+50 \mathrm{i} * 4+8 \mathrm{p} * 12+11 \mathrm{a} * 4+$ $4 \mathrm{mk} 6 \mathrm{rt}+\mathrm{m} 1 \mathrm{rt}+1 \mathrm{v} * 4+1 \mathrm{t}=\mathbf{1 8 2 4}$ особи;

1600: $7.5 \mathrm{lnp}+3 \mathrm{~nm}+186 \mathrm{ar} * 6+65 \mathrm{~h} * 4+48 \mathrm{i} * 4+8 \mathrm{p} * 12+6 \mathrm{~m} * 6$ (або 9rt*3) $+8.5 \operatorname{lnt}+10 \mathrm{t} * 6+2 \mathrm{v} * 4+11 \mathrm{a} * 4=\mathbf{1 8 1 2}(\mathbf{1 8 0 3}$ особи $)$;

1601: $8 \mathrm{lmp}+3 \mathrm{hm}+9 \mathrm{hnt}+189 \mathrm{ar} * 6+63 \mathrm{~h} * 4+52 \mathrm{i} * 4+8 \mathrm{p} * 12+10 \mathrm{t} * 6+7 \mathrm{~m} * 6$ (або $9 \mathrm{rt} * 3)+10 \mathrm{a}^{*} 4+2 \mathrm{v} * 4=\mathbf{1 8 4 0}$ (або 1825 осіб);

1609: $35 \mathrm{i} * 4+8 \mathrm{p} * 12+6 \mathrm{~m} * 6($ aбо $9 \mathrm{rt} * 3)+43 \mathrm{~h} * 4+3.5 \mathrm{hm}+5$ hat $+5 \mathrm{a} * 4+$ $7 * 6+1 \mathrm{v} * 4+66.5 \ln * 18=\mathbf{1 7 0 7}$ (або 1698 осіб).

Кількісний та етнічний склад населення. Окремі згадки про мешканців сіл маєтності та околиць в джерелах XV ст. вказують на те, що значна їх частина була українцями: Іван або Теплушка 3 Коцурова ${ }^{110}$; Зень Столпович 3 Романова ${ }^{111}$, Гаврило, Гриць ${ }^{112}$ та Миколай ${ }^{113} 3$ Шоломині, Лук'ян 3 Підгородища ${ }^{114}$, кметі з Монастиря Іван, Марич, Іван, Олекса і Волос ${ }^{115}$, пастух Анко (Іванко?) Лаєць ${ }^{116}$ та сіячі Устиян і Гринь 3 Гринева ${ }^{117}$, Мілечко 3 Будькова та Олекса 3 Глібович ${ }^{118}$, Клеменс 3 Лопушної ${ }^{119}$, Лець і Йош (Йосип) із Суходолу ${ }^{120}$, Флоріан зі Старого Села ${ }^{121}$, Сех з Глібович та Зень і Глібко із Суходолу ${ }^{122}$. Без точної вказівки на місце проживання згадані: кметі Петра Романовського Василь ${ }^{123}$ і Степан ${ }^{124}$, підданий Миколая Коцурівського

${ }^{110}$ AGZ. - T. 15. - S. 193, nr 1559 (24.III.1477; labor. Iwan alias Tepluschka de Coczarow).

${ }^{111}$ Ibid. - T. 19. - S. 518, nr 2884 (1475; Stephanum de Romanow in termino condempnabili condempnavit, quia tu sibi Ian noluisti ius ministrare cum homine tuo de Romanow nomine Zayn Stolpovycz).

${ }^{112}$ Ibid. - T. 15. - S. 516, nr 4098 (4.I.1482; duos homines super gsa. dom. Barbara de Stareszyolo, unum de Schalomyn nomine Hawrilo et alium Hricz eciam de Schalomyn).

${ }^{113}$ Ibid. - T. 14. - S. 339, nr 2614 (14.VII.1452; Nicolaum Officialem in Schalomvn).

114 Ibid. - S. 140, nr 1142 (28.VIII.1444; homini suo Luczyano); s. 141, nr 1145 (11.IX.1444; Nobil. Mathias nuncius dom. Nicolai Romanowski procurator ab homine ipsius domini sui Lukyano de Podhrodischcze).

${ }^{115}$ Ibid. - S. 337, nr 2597 (30.VI.1452; kmethonibus eius videlicet Iwan, Marycz, Iwan, Olexa et Voloss, reclinatos de Manastir).

${ }^{116}$ Ibid. - S. 386, nr 2935 (29.IX.1453; Wlodek nobilis de Przedrzyno alias de Coczvrow attemptavit terminum ab homine ipsius Anco Layecz pastuch de Hranyow).

${ }^{117}$ Ibid. - S. 381-382, nr 2906 (27.VII.1453; Vstian et Hryn seratorum de Hranyow).

${ }^{118}$ Ibid. - T. 15. - S. 491, nr 3865 (26.VI.1478; Milieczko de Budkow, Olexa in Hlebowicze).

${ }^{119}$ Ibid. - T. 14. - S. 5, nr 34 (15.VII.1440).

${ }^{120}$ Ibid. - S. 15, nr 111 (4.XI.1440; Iosch de Suchodol); s. 16, nr 116 (5.XI.1440; kmetonibus de Suchodol Leczoni videlicet et Ioschoni); s. 16, nr 117 (5.XI.1440; Leczoni et Ioschoni de Suchodol).

${ }^{121}$ Ibid. - S. 387, nr 2925 (1.XII.1499; Florianus, qui protune erat factor in Stareszyolo).

${ }^{122}$ Ibid. - S. 162, nr 1262 (28.IX.1473; Syech de Hlebowycze, und. Zayn de Svchodol, duod. Hleppko de ibidem).

${ }^{123}$ Ibid. - T. 14. - S. 102, nr 814 (14.VIII.1443; Vasyl kmetho stren. Petri Romanowski); s. 103, nr 816 (17.VIII.1443); s. 103, nr 818 (19.VIII.1443); s. 103, nr 819 (19.VIII.1443).

${ }^{124}$ Ibid. - T. 15. - S. 401, nr 3013 (17.VII.1500; Labor. Sthepan homo gsi. Petri Odnowski de Romanow). 
Манець 3 двома сестрами Федькою і Білкою ${ }^{125}$, слуги Романовського Петрик і шляхетний Войцех ${ }^{126}$, слуга Влодка Коцурівського Клеменс ${ }^{127}$.

Наведений вище перелік селян, які склали перед гродським судом Львова присягу про неможливість сплати податку через спустошення - не єдиний документ з XVII ст., де зафіксовані імена мешканців маєтності. У 1670 р. було проведено інвентарний опис сіл Городиславичі ${ }^{128}$, Під’ярків ${ }^{129}$ та містечка Миколаїв ${ }^{130}$ (перша віднайдена згадка про цей населений пункт). Ана-

${ }^{125}$ AGZ. - S. 491, nr 3858 (1.V.1478; nobil. Nicolai de Coczarow pro eo, quia tu sibi noluisti reddere hominem Manyecz cum duabus sororibus secum indivisis videlcet Phyedka et Byelka); s. $492, \mathrm{nr} 3871$ (26.VI.1478).

${ }^{126}$ Ibid. - T. 14. - S. 386, nr 2935 (29.IX.1453; Włodek. Włodek nobilis de Przedrzyno alias de Coczvrow attemptavit terminum ab homine ipsius Anco Layecz pastuch de Hranyow super Pyetrik servitore domini Romanowski, a quo nobil. Albertus servitor domini Romanowski reposuit secundum terminum simplici infirmitate).

${ }^{127}$ Ibid. - S. 417, nr 3152 (19.VIII.1454; Nobil. Clemens servitor Wlotkonis de Coczarow).

${ }_{128}$ Кметі на чвертях: Гриць Ямний, Кавтан, Захарчині, Кот, Прокоп, Боднар, Скаліш, Жила, Прейма, Хацко, Савицький, Нога, Гричик, Кавча, Дмитерко, Волошин, Ганс, Дацько, Федунець, Харко, Лучик, Кальний, Туз, Воляник, Василь і Хведь Бундзики, Гриць Мельників, Павел, Паскуш; підсадки: Конюх, Андрейко, Драб, Госіор, Ласко, Міхно Шавчик, Івасько, Данько, Зигмунт, Іван Чорний, Клачек, Чихало, Василь, Стецько Зельник; ткачіпідсадки: Цимбалістий, Іван Сліпий, Гудзко; ткачі-комірники: Щирба, Павел, Савицький; комірники 3 халупами: швець Яцко, Хващевський, Бочатиха, Владика, Костецький, Іван Волошин, Навілавський; комірники без халуп: Федько Качмар, Хиць (!) Федорців, Федько Дидів, Пасічник, Войтек, Іван Червоний, швець Кузьма, Савка, Яцко Преймин, Петрик, Демко. Окремо згадані піп і мельник (імена не вказані), Іван Ватаман та Маліновський. Якщо вважати, що під кожним вжитим у множині прізвищем (Захарчині тощо) йдеться про 2 осіб - всього згадано 72 мешканці (ЦДІАЛ. - Ф. 181 [Лянцкоронські], оп. 2, спр. 3119, арк. 7-8 = Там само. - Арк. 15-17).

${ }^{129}$ Кметі на чвертях: Чорній, Забіяка, Зорей, Дацько, Сова, Яцко Куріїв, Максим, Проділко, Бокатий, Стас, Курії, Лазур, Тресило, Антон, Захарка, Фурик, Бахрей, Яцко Лазорів, Ганулиць, Глинна, Міхур; комірники з городами і халупами: Гевко, Стецько Дебрин, Зинь, Карпиха, Максим, Василь Колесник. Окремо згаданий піп (ім'я не вказане); комірники без городів 3 халупами: Нечай, Павлиха, Дідуско, Пастернацька, Ігнатиха ткачиха, Кость; комірники бех халуп («komorniczy co w czudzych chałupach mieszkaią»): Васьо, Михайло, Процик, Варивода, Дебик Петро; ремісники (ткачі і швець): Мартин Чивка, Гаврило ткач, Іван Лазорів, Яцко швець. Оскільки сумарне число кожної з категорій мешканців було зазначене в самому документі, можемо впевнено говорити про 47 згаданих осіб (Там само. - Арк. 9 зв.-10 зв. $=$ Там само. - Арк. 17-18).

130 Іванко війт, Гриць Олекса, Луць Іловський, Левечко, Андрій Попадя, Бокатий, Бозара Старий, Цизм'як (?), Місько Козак, Андрій Солтис, Яцко Зинішин, Федір Зварич, Кунаш Бринецький, Гушоцька, Кунаш Савчишин, Михайло Скакун, Сень Цап, Гевко, Ілько Солтис, Іван Бастук, Федь Борис, Васько Різник, Дмитро Бродянський, Проць Нестеров'ят, Стецько Добрянський, Ярко Стелецький, Андрій Ричило, Василь Зварич, Василь Гриньків, Корнет, Ілько Федунчишин, Василь Тячлак (!), Луць Гаврилишин, Гаврилиха вдова, Ясько Якубовський; халупники «со swoie folwarki maią»: Василь Возний, Федько Карч, Павел Кисіль, Кобус, Кисельник, Кузьма Витрикушин, Матіяш, Позич, Щуцький, Петро Солтис, Сень Громецький, Андрій Турабський, Сенько Цапик, Петро Гевків, Анджей Столецький, Курило, Пилип Бринецький, Тимко Лавричин, Василь Цап, Блажей, Іваницький, Біловус; комірники 3 халупами: Василь Дробениця, Дмитро Кравець, Федь Боринський, Іван Столецький, Лукаш Пекар, Небор (Нестор?) Сіковський, Могрин Федько, Яцко Бабин, Кобало, Федь Коваль, Тимко Солтис; комірники без житла: Трач, Лех, Сухоцький, Василь Бранець, Місько Скрипек, 
ліз вміщених переліків імен місцевих жителів вказує на те, що абсолютна їх більшість була українцями.

Черговий віднайдений інвентар - цього разу усіх поселень маєткового комплексу - було укладено в 1763 р. Він також фіксує кількісне домінування українців. Загалом, серед 1382 власників домогосподарств нараховуємо лише 86 поляків (14 у Старому Селі, 1 у Будькові, 1 у Підмонастирі, 7 у Відниках, 4 у Гриневі, 2 у Волощині, 7 у Суходолі, 18 у Глібовичах, 8 у Звенигороді, 2 у Городиславичах, 1 у Миколаєві, 2 у Під’яркові, а також все населення Гутиська - 19 осіб). Свреїв ще менше - 21 (1 у Старому Селі, 1 у Підмонастирі, 1 у Відниках, 2 у Суходолі, 3 у Глібовичах, 2 у Звенигороді, 10 у Городиславичах, 1 у Підсоснові) ${ }^{131}$. Однак, слід зауважити, що реєстр збору поголовного податку серед юдеїв 1764-1765 рр. містить зовсім інші дані. Так, лише в одному містечку Миколаїв зафіксовано 98 сповідників Мойсеєвої віри, тоді як загальне число євреїв Старосільської маєтності за реєстром становило на той період 388 осіб $^{132}$.

Враховуючи, що інвентар охоплює лише очільників домогосподарств, загальне число мешканців ключа (при коефіцієнті 6) за документом 1763 р. становить близько 8300 осіб. Якщо ж припустити, що число євреїв за реєстром збору поголовного податку містить більш вірогідні дані ${ }^{133}$, то ми отримуємо наступну кількість населення маєтності - 6*(1382-21) $+388=$ 8554 особи.

Взагалі, слід відзначити, що третя чверть XVIII ст. для досліджуваних теренів у джерельному відношенні була дуже насиченою. Саме в цей період проведено чергову візитацію церков Львівсько-Галицько-Кам’янецької єпархії (1758-1765 рр.). Демографічні параметри стосовно парафіян подає також шематизм 1763-1765 pр. (див. таблицю 4). Згідно його даних, на території Старосільського ключа мешкало $8312+782=9094$ особи, а разом 3 євреями (згідно реєстру) - $9094+388=9482$ мешканців. Якщо ж прийняти

Ілько Порицький, Федь Болотний, Роман Голецький; інші комірники: Коханка, Феська, Гевка, Місько Шинкар, Сень у Зварича, Артим, Маруська у Яцка; ткачі: Ілько, Юрант, Сень Валовий, Проць, зять (?); шевці: Войцех, Данило, Іван Валовий. Окремо згадані піп (ім'я не вказане), а також Сапіга, Магер, Мелех, Юсько, Міхель. Всього 97 осіб (ЦДІАЛ. - Ф. 181, оп. 2, спр. 3119, арк. 11-12 зв. = Там само. - Арк. 18-19 зв.).

${ }_{131}$ AGAD. - Archiwum Potockich z Lańcuta, sygn. 43/1, 54 k.

132 Населені пункти маєткового комплексу адміністративно належали до двох кагалів Бібрківського: Будьків - 11 осіб, Вільхівець - 4, Глібовичі - 51, Гринів - 11, Лопушна - 4, Підмонастир - 4, Старе Село - 9, Суходіл - 11, Шоломия - 13; всього 118) та Свірзького (Відники - 54, Городиславичі - 10, Звенигород - 32, Коцурів - 11, Миколаїв - 98, Підгородище 20, Підсоснів - 9, Під’ярків - 12, Романів - 19, Селиська - 5; всього 270) (Bostel F. Żydzi ziemi lwowskiej i powiatu żydaczowskiego w r. 1765 // [Odbitka z:] Archiwum komisji historycznej. Kraków, 1891. - T. 6. - S. 10, 18).

${ }_{133}$ Параметри інвентаря (21 очільник домогосподарства) і реєстру (388 осіб) стосовно юдеїв не можна вважати однаково достовірними, оскільки за ними виходить, що одне єврейське домогосподарство складалася в середньому з 18-19 осіб. 
до уваги число греко-католиків за списками не 1763, а 1765 р. $-782+4874+$ $1352+388=7396$ осіб.

Таблиця 4. Населення Старосільського ключа за шематизмом 1763-1765 pp.

\begin{tabular}{|c|c|c|c|c|}
\hline \multirow[b]{2}{*}{ Населений пункт } & \multicolumn{2}{|c|}{ Списки 1763 р. } & \multicolumn{2}{|c|}{ Списки 1765 р. } \\
\hline & $\begin{array}{c}\text { Греко- } \\
\text { католики }\end{array}$ & $\begin{array}{c}\text { Римо- } \\
\text { католики }\end{array}$ & $\begin{array}{c}\text { «Здатні } \\
\text { до сповіді» } \\
\text { греко- } \\
\text { католики }\end{array}$ & $\begin{array}{c}\text { Діти } \\
\text { до } 7 \text { років } \\
\text { («не здатні до } \\
\text { сповіді») }\end{array}$ \\
\hline Будьків & 250 & 50 & 182 & 36 \\
\hline Великі Глібовичі & 658 & 151 & 554 & 100 \\
\hline Відники & 338 & 48 & 275 & 88 \\
\hline Вільховець & 204 & 6 & 120 & 47 \\
\hline Волове та монастир Підгородища & 54 & 76 & - & - \\
\hline Волощина & 294 & 22 & 115 & 40 \\
\hline Гаї & 440 & 40 & - & - \\
\hline Городиславичі & 625 & 53 & 479 & 137 \\
\hline Гринів & 721 & 3 & - & - \\
\hline Звенигород & 940 & 138 & 526 & 158 \\
\hline Коцурів & 176 & 11 & - & - \\
\hline Лопушна & 273 & 6 & 123 & 28 \\
\hline Миколаїв & 395 & 37 & 308 & 80 \\
\hline Підгородище & 523 & 39 & 406 & 130 \\
\hline Підмонастир & 237 & 0 & 175 & 49 \\
\hline Підсоснів & 346 & 4 & 280 & 50 \\
\hline Під’ярків & 533 & 39 & 420 & 110 \\
\hline Романів & 553 & 33 & 446 & 124 \\
\hline Селиська & 220 & 22 & - & - \\
\hline Старе Село & 253 & $?$ & 250 & 55 \\
\hline Суходіл & 279 & 4 & 215 & 120 \\
\hline ВСЬОГО & 8312 & 782 & 4874 & 1352 \\
\hline
\end{tabular}

Примітки: Лаба В. Перший галицький церковний шематизм 1763-65 років. - Львів, 2002. - С. 11-12, 18-19.

Вважаємо за необхідне також звернути увагу на матеріали попередньої візитації (1738-1744 рр.), найважливіші відомості якої (хоч і приблизні) вміщено у таблицю 5. 


\section{Таблиця 5. Генеральна візитація 1738-1744 рр. про церкви Старосільського ключа (Бібрківське намісництво} Львівського крилосу) $)^{134}$

\begin{tabular}{|c|c|c|c|}
\hline $\begin{array}{c}\text { Населе- } \\
\text { ний пункт }\end{array}$ & $\begin{array}{c}\text { Посвята } \\
\text { церкви }\end{array}$ & \begin{tabular}{|c|} 
Дата проведення \\
візитаціі, місце \\
зберігання джерела \\
\end{tabular} & $\begin{array}{l}\text { Ім'я пароха і колятора, } \\
\text { число парафіян }\end{array}$ \\
\hline Будьків & $\begin{array}{l}\text { Воздвижен- } \\
\text { ня Чесного } \\
\text { Хреста }\end{array}$ & $\begin{array}{l}18 \text { III 1742; } \\
\text { НМЛ, Ркл-17, } \\
\text { арк. 2923в.-293 }\end{array}$ & $\begin{array}{l}\text { Парох о. Григорій Валенникевич; } \\
\text { Август і Марія-Зоф’я Чарторийські1 }{ }^{135} \text { (подружжя); } \\
45\end{array}$ \\
\hline Вільховець & $\begin{array}{l}\text { Пресвятої } \\
\text { Тройці }\end{array}$ & $\begin{array}{l}16 \text { III 1742; } \\
\text { Там само, } \\
\text { арк. 288-288зв. }\end{array}$ & $\begin{array}{l}\text { Парох о. Теодор Гавронський (?); } \\
\text { Август і Марія-Зоф’я Чарторийські (подружжя); } \\
22\end{array}$ \\
\hline Волощина & $\begin{array}{l}\text { Вознесення } \\
\text { Господнього }\end{array}$ & $\begin{array}{l}18 \text { III 1742; } \\
\text { Там само, } \\
\text { арк. 2933в.-294 }\end{array}$ & $\begin{array}{l}\text { Парох о. Йосип Тарлецький; } \\
\text { Август і Марія-Зоф’я Чарторийські (подружжя); } \\
\text { близько } 40\end{array}$ \\
\hline Глібовичі & $\begin{array}{l}\text { Свв. Косми } \\
\text { і Дам’яна } \\
\text { Безсрібників }\end{array}$ & $\begin{array}{l}19 \text { III } 1742 ; \\
\text { Там само, } \\
\text { арк. 294-295 }\end{array}$ & $\begin{array}{l}\text { Парохи оо. Іван Терлецький і Данило Михай- } \\
\text { лович; Август і Марія-Зоф’я Чарторийські } \\
\text { (подружжя); } 120\end{array}$ \\
\hline Лопушна & $\begin{array}{l}\text { Воскресення } \\
\text { Христового }\end{array}$ & $\begin{array}{l}17 \text { III 1742; } \\
\text { Там само, } \\
\text { арк. 2883в.-289зв. }\end{array}$ & $\begin{array}{l}\text { Парох о. Іван Левицький; } \\
\text { Август і Марія-Зоф’я Чарторийські (подружжя); } \\
30\end{array}$ \\
\hline $\begin{array}{l}\text { Підмо- } \\
\text { настир }\end{array}$ & $\begin{array}{l}\text { Благовіщення } \\
\text { Пресвятої } \\
\text { Богородиці } \\
\end{array}$ & $\begin{array}{l}18 \text { III 1742; } \\
\text { Там само, } \\
\text { арк. 293-2933в. }\end{array}$ & $\begin{array}{l}\text { Парох о. Іван Керницький; } \\
\text { Август і Марія-Зоф’я Чарторийські (подружжя); } \\
16\end{array}$ \\
\hline $\begin{array}{l}\text { Старе } \\
\text { Село }\end{array}$ & $\begin{array}{l}\text { ц-ва відсут- } \\
\text { ня }^{136}\end{array}$ & $\begin{array}{l}17 \text { III 1742; } \\
\text { Там само, } \\
\text { арк. 291-291зв. }\end{array}$ & $\begin{array}{l}\text { Парох о. Василь Грабович; } \\
\text { Август і Марія-Зоф’я Чарторийські (подружжя) }\end{array}$ \\
\hline Суходіл & $\begin{array}{l}\text { Покрову } \\
\text { Пресвятої } \\
\text { Богородиці }\end{array}$ & $\begin{array}{l}16 \text { III } 1742 ; \\
\text { Там само, } \\
\text { арк. 2873в. }-288\end{array}$ & $\begin{array}{l}\text { Парох о. Андрій Підлісецький }{ }^{137} ; \\
\text { Август і Марія-Зоф’я Чарторийські (подружжя); } \\
30\end{array}$ \\
\hline Шоломия & $\begin{array}{l}\text { Св. Іллі } \\
\text { Пророка }\end{array}$ & $\begin{array}{l}17 \text { III 1742; } \\
\text { НМЛ, Ркл-17, } \\
\text { арк. 291зв.-292зв. }\end{array}$ & $\begin{array}{l}\text { Парох о. Іван Маркевич; } \\
\text { Август і Марія-Зоф’я Чарторийські }{ }^{138} \text { (подружжя); } \\
60\end{array}$ \\
\hline
\end{tabular}

Примітки: загальне число парафіян, зазначених у таблиці - 363.

${ }^{134}$ Окрім матеріалів самої візитації, використано працю: Скочиляс I. Генеральні візитації Київської унійної митрополії XVII-XVIII століть. Львівсько-Галицько-Кам'янецька єпархія. Львів, 2004. - Т. 2. - С. 149-150.

${ }^{135}$ В тексті коляторами помилково зазначені Четвертинські: Kollacyi Jasnie Oswieconych xięstwa Czetwertynskich w[oje]w[o]dow ruskich małżonkow (Національний музей у Львові (далі скорочення: НМЛ), Рукописи кириличні і латинські (далі скорочення: Ркл)-17, арк. 291 зв.-292).

${ }^{136}$ Cerkwi w tey parochyi niemasz od lat pięci iak pogorzała, cmentarz parkanem obstawiony, na ktorym dzwonnica cum campanis quatuor, w nieyze kaplica tituli S[ancti] Nicolai episcopi (НМЛ, Ркл-17, арк. 291).

${ }^{137}$ Підлісецькі віддавна були парохами села. У документі закладення церкви в селі Бродки Щирецького староства від 30 квітня 1571 р. згадується парох із с. Суходіл Федір Підлісецький: Nobili ac religioso Fedoris Podlesieczki poponi in Suchodoł (ЦДІАЛ. - Ф. 9, оп. 1, спр. 378, с. 3146).

${ }^{138}$ В тексті коляторами помилково зазначені Четвертинські: Collationis Jasnie Oswieconych xiązat ichm[os]ciow Czetwertynskich w[ojewo]dow ruskich małżonkow (НМЛ, Ркл-17, арк. 291 зв.-292). 
Історію сакральних об'єктів комплексу слід розпочати із Старого Села, де в 1454 р. Ян Завішич фундував костел Всемогутнього Бога, Діви Марії та Святої Трійці. Наступні власники ключа - Тарновські - у 1486 р. надали цьому храму у власність корчму ${ }^{139}$. Про наявність церков на території маєтності і в сусідніх селах у XV ст. свідчать записи в актових книгах (згадуються священик зі Звенигорода ${ }^{140}$, попи Кузьма (Косьма) 3 Суходолу ${ }^{141}$, Левко ${ }^{142}$ з Відник та Міхно з Романова ${ }^{143}$. Поборові реєстри першої половини XVI ст. засвідчують присутність сакральних об'єктів (хоч вони і зазнавали спустошень) в усіх селах ключа, за винятком новозакладеного Вільхівця (див. табл. 2). Джерела другої половини XVI ст. (реєстр 1552 р.) фіксують священика і тут (див. таблицю 3).

Обителі Старосільського ключа та їх парохи також отримували привілеї. Зокрема, кн. Василь-Костянтин Острозький, який сприяв появі нових православних храмів в маєтності ${ }^{144}, 23$ червня 1596 р. написав з Дубна листа управителю ключа Войцеху Конському про довічне надання монахам земельних угідь на горі в с. Шоломия (тут стояла т. зв. «горішня» церква - на думку В. Лаби це була церква св. Іллі, яка знаходилася на цьому місці до 1717 р.). Ченці займали обитель після смерті священика Стефана Кончака, щоб вона не пустувала. Це було зроблено на прохання місцевого пароха «долішньої» церкви Михайла Лепели. У листі Острозький застеріг Конського, аби той не чіпав монахів ${ }^{145}$.

${ }^{139}$ Відповідні документи - фундації (1454 р.) і надання (1486 р.) збереглися лише у копіях (до нашого часу дійшли два їх повних тексти: у львівських гродських актах (впис від 3 вересня 1605 р.: ЦДІАЛ. - Ф. 9, оп. 1, спр. 393, с. $982-984$ (1454 р.); с. 984-986 (1486 р.)) та у консисторських книгах Архіву Львівської римо-католицької архідієцезії в Кракові (впис від 1 грудня 1605 p.: Archiwum Archidiecezji Lwowskiej w Krakowie. - Księgi konsystorskie, t. 5, k. 229-229 v. (1454 p.); k. 230-230v (1486 p.)). Вони опубліковані Станіславом Тилюсом з краківської копії (документ 1486 р. був виданий також в «Aktach grodzkich i ziemskich» на основі тексту втраченого оригіналу, що зберігався у Консисторському архіві у Львові (AGZ. - T. 3 / [Oprac. O. Pietruski, X. Liske]. - Lwów, 1872. - S. 249-251, nr 128)). Порівняння з «львівською» копією засвідчує незначні текстові розходження (Tylus S. Fundacje kościołów parafialnych w średniowiecznej archidiecezji lwowskiej. - Lublin, 1999. - S. 206-208, nr 41; s. 208-211, nr 42; регести: AGZ. - T. 10. - S. 7, nr 109; s. 10, nr 158).

${ }^{140}$ AGZ. - T. 14. - S. 96, $\mathrm{nr} 760$ (31.V.1443; popone de Vynnigrod).

${ }^{141}$ Ibid. - T. 15. - S. 339-340, nr 2562 (25.VIII.1497; Kosma popone de Svchodol mfi. dom. Iohannis Amor de Tarnow Cstli. Cracov.); s. 354, nr 2668 (приблизно 4.V.1498); s. 355, nr 2682, 2684 (22.VI.1498).

${ }^{142}$ Ibid. - S. 167, nr 1304 (17.XII.1473; pop Lewko de Vodnyky).

${ }^{143}$ Ibid. - S. 483, nr 3802 (1476; homine pop ipsius Stephani nomine Michno de Romanow); t. 19. - S. 517, nr 2882 (5.VI.1475; pop ruthenicali tuo de Romanow nomine Michno).

144 За даними А. Шнайдера, за дідицтва князя у Старому Селі була закладена православна церква Усікновення Голови Св. Івана Хрестителя (Schneider A. Staresioło pod Lwowem. - S. 9).

145 Лаба В. Історія села Шоломия. - С. 33 (Автор посилається на: ЦДІАЛ. - Ф. 159 [Галицька фінансова прокуратура, м. Львів], оп. 9, спр. 312, с. 2; Петрушевич А. Лингвистическо-исторические изследования о начатках города Львова и окрестностей его. - Львов, 1893. - С. 381). Привілей шоломинським ченцям було підтверджено 26 серпня 1743 р. і вписано у львівські гродські акти 9 червня 1751 р.: 
13 грудня 1689 р. король Ян Собеський відповідним актом звільнив о. Григорія Левицького в Романові від усіх данин і повинностей ${ }^{146}$. Двічі привілеї на земельні угіддя отримував василіянський монастир св. Спаса у Підгородищі ${ }^{147}$. У 1720 р. Адам-Миколай Сенявський на прохання ігумена Інокентія Зенковського подарував монастирю поле. Тоді ж при монастирі було збудовано дерев'яну церкву. В 1738 р. черговий привілей на грунти монастирю надав кн. Август Чарторийський ${ }^{148}$. Зауважимо, що в Підгородищі, окрім чоловічого василіянського, певний час існував також жіночий монастир ${ }^{149}$.

Висновки. Таким чином, Старосільський ключ сформувався як приватний маєтковий комплекс ще у кінці XIV ст. Осердям його території була Звенигородська волость княжих часів, центр якої із заснуванням Львова втратив своє політичне і адміністративне значення. Це позначилося й на факті існування самої волості. Певний період (з кінця XIV до XVII ст.) територію ключа складав ряд поселень на межі Грядового Побужжя і Львівського

Konstantyn xiąze, wojewoda kijowski, marszałek ziemi wołynskiey, starosta włodzimirski.

Namiesnikowi naszemu starosielskiemu urodzonemu Woyciechowi Końskiemu y po tobie będącym.

Oznaymuyemy wam, iz prosił nas przez supplikę donosząc Michayło Lepieła, iz cerkiew gurna szołomynska juz blisko roku po smierci oyca Stefana Konczaka, niemającego po sobie zadnego nastempcy bez nabozenstwa proznuje, abysmy na tę mieysce na czas zakonnikow do odprawy sprowadzić pozwolili. Więc my chcac y ządając sobie tego aby chwała Boza nigdy nie ustawała, na prozbę poboznego Michała Lepieły, do tey cerkwi parochialney zakonnikow sprowadzic pozwalamy. Ktorym to zakonnikow jako y przedtym będącym parochialnym szwieszczennikom do przodkow naszych im wiecznie nadaną gurę w koło od sadow dolnych, a od pobocznego az do gornego Cepiełowego okopu idącą nieodmiennie do uzywania potwierdzamy. Wedle ktorego to naszego na to im od nas z pieczęcią y z podpisem własney ręki naszey danego listu abys ty y po tobie będący urzędnicy y wszelakie dzierzawcy te swięte mieysce z pomienionemi okolicznosciami bez zadnego nagabania w całosci zachowywali.

Dan w Dubnie roku tysiącznego pięcsetnego dziewiendziesiątego szostego, czerwca trzynastego dnia.

(ЦДІАЛ. - Ф. 9, оп. 1, спр. 562, с. 1545-1546). На цей документ звернув нашу увагу Андрій Фелонюк, за що висловлюємо йому подяку.

${ }^{146}$ Там само. - Спр. 458, с. 2724-2726 (регест: AGZ. - T. 10. - S. 361, nr 6049).

${ }^{147}$ Монастир василіян вперше згадується у 1674 р. В 1744 р. його було офіційно закрито, однак лише в 1756 р. обитель покинув останній монах (Лаба В. Історія села Підгородище... C. 11; SG. - T. 8. - S. 399).

148 Лаба В. Історія села Підгородище... - С. 11; SG. - Т. 8. - S. 399.

${ }^{149}$ Про нього відомо дуже мало. Василь Лаба в якості єдиної згадки про жіночий монастир у Підгородищі вказує на Євангеліє 1690 р. 3 написом, що його в 1705 р. придбала у Львові інокиня Свпракседа Любецька за власні кошти (30 злотих) «за приводом панни ігумені» (Лаба B. Історія села Підгородище... - С. 11; ЦДІАЛ. - Ф. 201 [Греко-католицька митрополича консисторія, м. Львів], оп. 1в, спр. 2255, с. 8). На думку Олега Духа, інокиня Свпракседа мала відношення до Бібрецького монастиря (ймовірно, це була Євпраксія Кандидянка - 1706-м роком датується іiі впис до помяника Підгородищенського монастиря) (Дух О. Превелебні панни. Жіночі чернечі спільноти Львівської та Перемишльської єпархій у ранньомодерний період. Львів, 2017. - С. 556). 


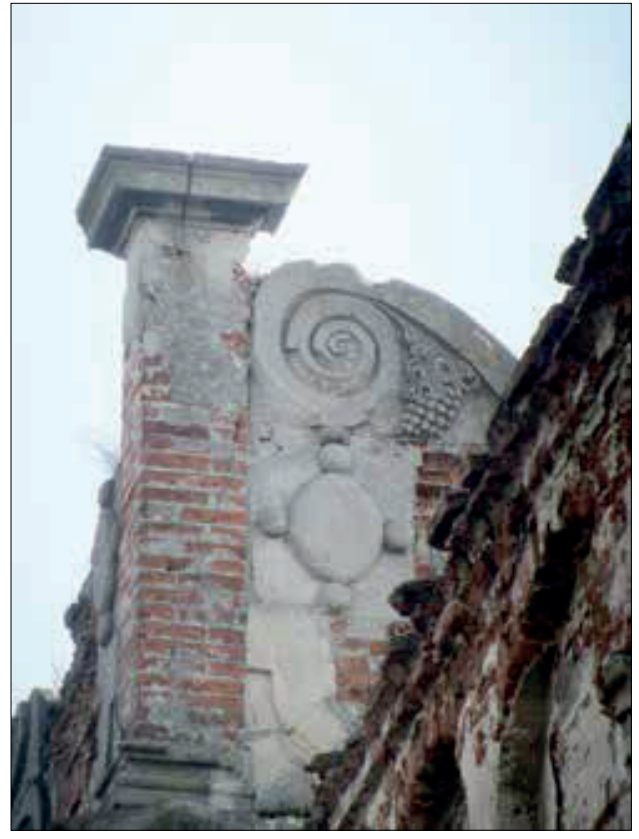

Іл. 1. Замок у Старому Селі. Фрагмент оздоблення аттика східної вежі

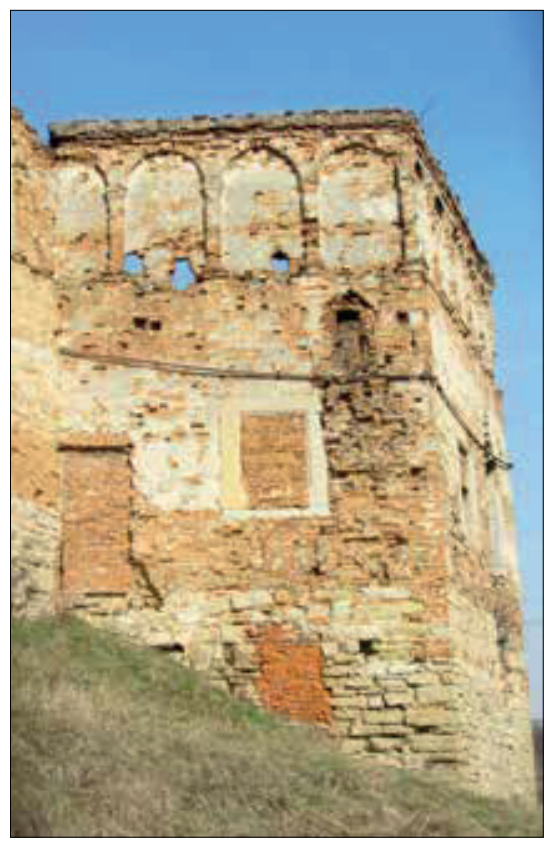

Іл. 2. Замок у Старому Селі. Південно-східна вежа

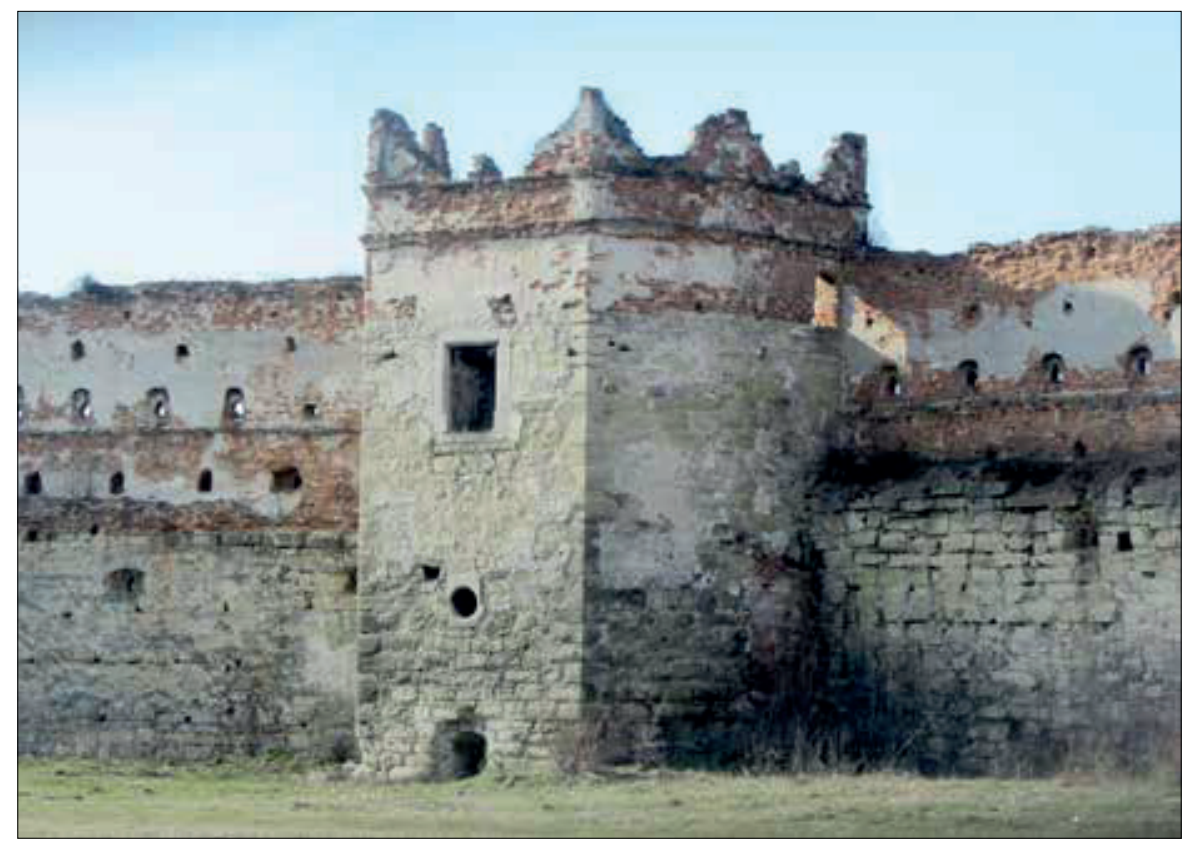

Іл. 3. Замок у Старому Селі. Північна вежа з аттиком у дусі маньєризму 
Опілля, зосереджених довкола Старого Села у володінні спочатку місцевих урядників (Михайло Жаба, Дмитро з Горая), а згодом - прибулої шляхти (Куровських $\rightarrow$ Завіш $\rightarrow$ Тарновських $\rightarrow$ Острозьких і Заславських $\rightarrow$ Любомирських та Сенявських $\rightarrow$ Чарторийських $\rightarrow$ Потоцьких). Центр маєтності, разом із сусідніми поселеннями, був локований на німецькому праві як один населений пункт - Старе Село. Поступово до ключа входили довколишні приватні (Коцурів, Гринів, Звенигород) та королівські (Підсоснів, Під’ярків, Гаї, Відники) села. Ними володіли місцеві роди руського походження (Романовські, Ходорівські) або ж прибулі з інших воєводств шляхтичі (Карнковські, Коритки, Голдачі).

В етнічному відношенні населення маєтності було, в основному, українським. Про це свідчать, як спорадичні згадувані імена окремих осіб в актових документах XV-XVIII ст., так і матеріали описово-статистичних джерел 3 обширними переліками очільників домогосподарств, комірників, сільських ремісників та ін. Етнічне співвідношення вплинуло і на витворення мережі сакральних об'єктів - якщо православні (пізніше - греко-католицькі) церкви були у кожному селі ключа, то костел існував лише у Старому Селі. Джерела містять згадки й про чернечі згромадження - як чоловічі (Шоломия, Підгородище), так, за деякими даними, і жіночі (Підгородище). Власники маєтності у різний період надавали парохам та настоятелям різного роду привілеї.

Про приблизне число мешканців ключа ствердно можемо говорити лише з середини XVIII ст., з появою низки різного роду джерел - господарського інвентаря, шематизму та візитації, реєстру збору поголовного податку серед євреїв. За різними даними, у цей час тут проживало від 8 до 9 тисяч осіб. На нашу думку, незважаючи на спустошення внаслідок татарських нападів і воєнних лихоліть доби Хмельниччини, в демографічному відношенні маєтність динамічно розвивалася - на це вказують як матеріали поборових реєстрів другої половини XVI ст. (незважаючи на умовність обраних нами методик обчислення, на їх підставі можемо говорити про тенденцію до зростання чисельності мешканців ключа), так і факт появи нових поселень впродовж XVII-XVIII ст. (Ваньківці, Гутисько, Гута Суходільська). Сприяла цьому в т. ч. розвинута інфраструктура - часто у селах маєтності існували не лише млини і корчми, а й окремі лани у володінні їх власників. Також джерела часто згадують про присутність тут ремісників.

Ще одна особливість ключа полягала в тому, що в ньому довгий час не було міських поселень. Романів (де ще у XV ст. міг існувати невеликий замок) та Підгородище не зберегли надані їм у XVI ст. міські права; локований на сухому корені Миколаїв перестав бути містом після занепаду Речі Посполитої. 
У період, коли Старим Селом з околицею володіли князі Острозькі й Заславські (1570-1658 рр.), з маєтністю, на перший погляд, не відбулося суттєвих змін - тут не було локовано жодного міста, не з'явилося жодне нове село, не фіксуємо жодних територіальних набутків чи втрат. Почасти, це було спричинено периферійним положенням маєткового комплексу по відношенню до основного осередку володінь Острозьких. Серед низки ключів, цей «посаг Барбари Тарновської» мав для родини другорядне значення - на це промовисто вказує той факт, що кн. Василь-Костянтин Острозький побував у Старому Селі лише двічі.

3 іншого боку, центр маєтності - Старе Село, що містом так і не став, саме завдяки Заславським укріпив свою обороноздатність. Острозькі ж, навіть не перебуваючи в маєтності, проявляли піклування іiі справами (на що вказує хоча би лист князя Василя-Костянтина своєму управителю стосовно шоломийських ченців). 